\title{
Immunohistochemical investigation of prognostic biomarkers in resected colorectal liver metastases: a systematic review and meta-analysis
}

\author{
William Torén, Daniel Ansari and Roland Andersson * (1)
}

\begin{abstract}
Background: Many studies have investigated the prognostic role of biomarkers in colorectal liver metastases (CRLM). However, no biomarker has been established in routine clinical practice. The aim of this study was to scrutinize the current literature for biomarkers evaluated by immunohistochemistry as prognostic markers in patients with resected CRLM.

Methods: A systematic review was performed according to the PRISMA guidelines. Articles were identified in the PubMed database with selected search terms and by cross-references search. The REMARK quality criteria were applied. Markers were included if they reported the prognostic impact of immunohistochemical markers in a multivariable setting in relation to overall survival (OS). A meta-analysis was conducted when more than one original article provided survival data of a marker.

Results: In total, 26 biomarkers were identified as independent significant markers for OS in resected CRLM. These biomarkers were found to be involved in multiple oncogenic signalling pathways that control cell growth, apoptosis, angiogenesis and evasion of immune detection. Among these biomarker candidates were Ki-67, EGFR, p53, hTERT, CD34, TSP-1, KISS1, Aurora kinase A and CDX2. CD34 and TSP-1 were reported as significantly associated with survival by more than one study and where therefore pooled in a meta-analysis.

Conclusion: A number of independent prognostic biomarkers for resected CRLM were identified. However, most markers were evaluated in a retrospective setting with small patient cohorts, without external validation. Large, prospective, multicentre studies with standardised methods are needed before biomarkers can translated into the clinic.
\end{abstract}

Keywords: Colorectal liver metastasis, Biomarkers, Prognosis, Immunohistochemistry, Tissue microarray

\section{Background}

Colorectal cancer is the third most common type of malignancy in the Western world and represents a leading cause of death worldwide [1,2]. Within 3 years of diagnosis, approximately $30 \%$ of patients develop metastases located in the liver [3]. For colorectal liver metastases (CRLM) surgical resection is the preferred treatment, providing patients a 5-year survival of up to

*Correspondence: roland.andersson@med.lu.se

Department of Surgery, Clinical Sciences Lund, Lund University and Skåne University Hospital, SE-221 85 Lund, Sweden
$60 \%$ [4]. However, CRLM is a heterogeneous disease and prediction of individual outcomes after surgery remains a challenge [5]. To improve prognostication in resectable CRLM, much research efforts have been dedicated into prognostic and predictive variables. A scoring system called the clinical risk score has shown to be valuable for estimation of prognosis in several studies [6-8]. Prognostic factors used in this model include resection margin status, extrahepatic disease, node-positive primary colorectal cancer, disease free-interval from primary to metastases, number of hepatic tumours, largest hepatic tumour and carcinoembryonic levels [6]. Over 
time, several predictive models have been designed to more precisely estimate long-term prognosis using clinical characteristics [9]. Even though these scoring systems have been proven to be useful to some extent, patients with similar risk scores may display varying outcomes. Therefore, a biological approach to stratify patients into risk categories is essential for more accurate prediction of disease outcome.

The molecular transformation of primary colorectal cancer is traditionally reported to involve accumulation of four key mutations, including the oncogenes APC, KRAS, DDC, and the tumour suppressor p53 [10]. Yet, studies have shown that this somatic mutation sequence only occurs in $10 \%$ of tumours [11]. Instead, alternative pathways are thought to occur in most cases of primary colorectal cancer $[12,13]$. Additionally, further adaptions are required to acquire metastatic capacity and potentiate spread to the liver. The variety of molecular pathways in primary colorectal cancer (CRC) and CRLM may explain the heterogeneity seen both biologically and clinically. Investigation into biomarkers that can enable more precise estimation of prognosis and response to therapy could potentially function as treatment targets and also decrease overtreatment. The benefits of a molecular approach to selection of treatment have been displayed in diseases such as breast cancer [14].

Immunohistochemistry (IHC) is a commonly used staining method where selective antibodies are utilised to quantify and assess distribution of molecular markers in tumour tissue. While other more advanced methods such as quantitative reverse transcriptase-polymerase chain reaction, cDNA microarray and fluorescence in situ hybridization are successively becoming more regularly used in clinical practice, they lack the practical properties of IHC and have not yet become part of routine analysis.

With the increasing interest of biomarkers as prognostic and predictive indicators of outcome, a great number of studies have presented correlations between markers of tumour biology and clinical outcome. However, interstudy differences in methodology, patient characteristics, statistical method and endpoint make the existing data difficult to interpret. The purpose of this study was to summarize the currently available literature on immunohistochemical biomarkers for predicting outcome after liver resection of CRLM.

\section{Methods}

An electronic search of the PubMed database of the National Library of Medicine was executed by the first author to identify all applicable articles. For this systematic review, the PRISMA guidelines were applied [15]. Linked and exploited search terms were 'colorectal' 'hepatic' 'liver' 'metastasis' 'metastases' 'prognosis' 'survival' immunohistochem"'. The initial search identified 1073 records. Titles implicating irrelevant subjects were not further studied. Abstracts were screened, and a selection was made based on whether the article could potentially meet the inclusion criteria. Abstracts with relevant content were read in full text to examine eligibility. References identified in the original search where crosschecked for additional eligible articles. The search ended November 2, 2018.

To be eligible for inclusion, the study the biomarkers had to be (1) evaluated in resected CRLM, (2) use IHC, (3) adhere to the REMARK quality criteria [16] and (4) include a minimum of 50 patients. When using tissue microarray (TMA) methodology, the technique had to be described in detail including information about protocols, antibodies, reagents, quantification and interpretation. If more than one articles provided data on the same patient set, only the most recent study was included. No contact was made with authors to collect unpublished data, as this review was limited to records that can be identified through electronic searches in public databases. Studies presented in other languages than English were excluded.

Only studies presenting overall survival (OS) in a multivariable setting, with associated hazard ratio (HR), were included. Additionally, a study had to present $95 \%$ confidence interval (CI) and $p$ value. If a study did not present a desired parameter, the study was still included if sufficient published data were included to estimate the parameter. If more than one article provided sufficient data of a biomarker, a meta-analysis was performed. The additional calculations and the conduction of metaanalysis were made using Review Manager (RevMan) [Computer program] Version 5.3: The Nordic Cochrane Centre, The Cochrane Collaboration, 2014.

\section{Results}

The search strategy is depicted in Fig. 1. A total of 26 biomarkers identified in 25 articles met the inclusion criteria (Table 1). The markers were categorized according to the hallmarks of cancer, as defined by Hanahan and Weinberg [17]: sustaining proliferative signalling, evading growth suppressors, resisting cell death, enabling replicative immortality, inducing angiogenesis, activating invasion and metastasis. Three additional categories were added: deregulated metabolism, controlling the immune system, genome instability (Table 1). Several biomarkers had multiple oncogenic functions, fulfilling criteria for more than one hallmark. In these cases, the markers were categorized in the group according to their most documented mechanism, based on current data of their role in CRLM. 


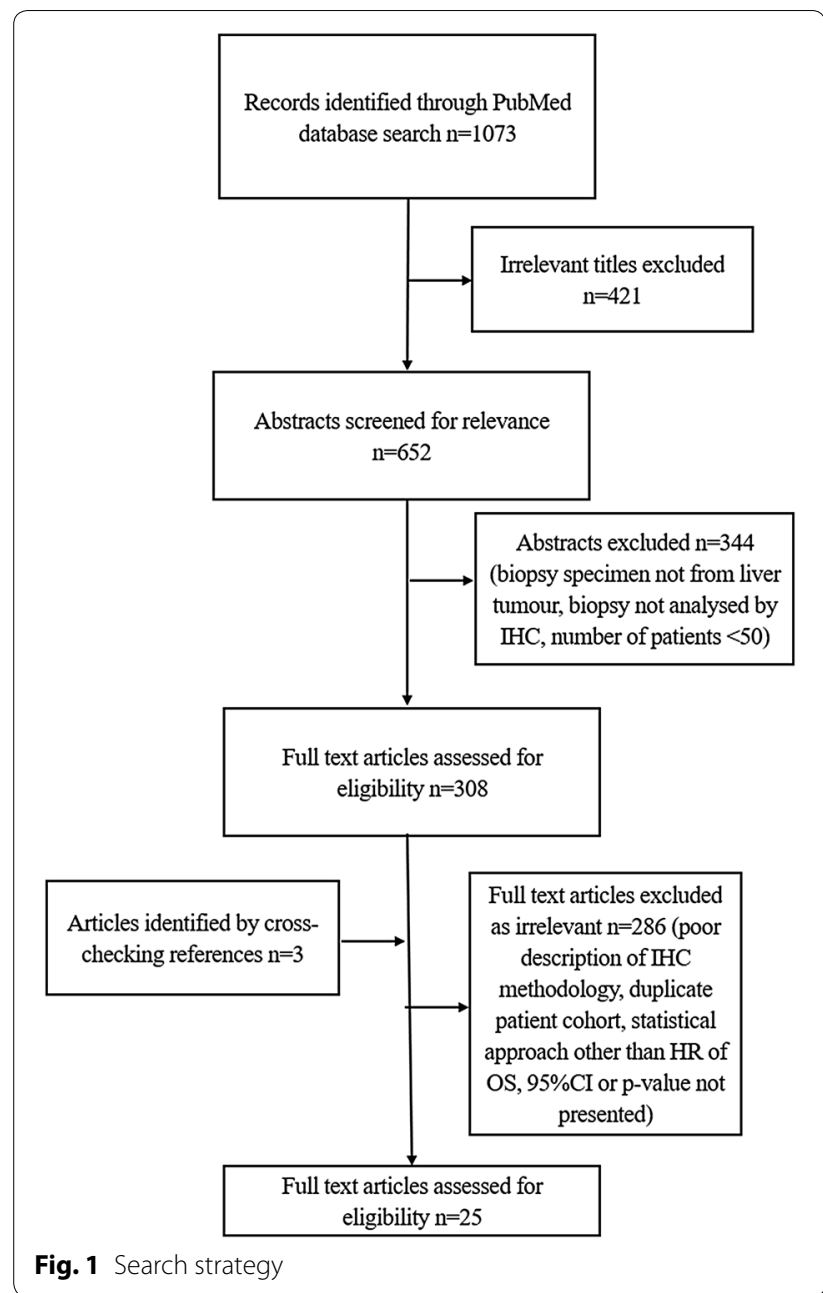

Frizzled related protein (FRZB)

FRZB is a negative regulator of Wnt signalling affecting many physiologic functions within the human body [18]. Beta-catenin is one of two pathways that can be activated through Wnt signalling. This pathway is one of the pivotal pathways in stemness and embryonic development. It regulates levels of signalling proteins such as COX-2 and MMP3, which both have documented functions in tumour development [18, 19]. Through this key regulatory function, FRZB has been found as an important oncogene that initiates metastatic properties in human cancers [20]. Approximately two-thirds of CRLM display strong FRZB IHC staining [21], which indicates an upregulation compared to primary CRC [22]. One study analysing the correlation between FRZB and survival in resected CRLM was eligible for this review [21]. In this study, positive IHC staining was found as a significant prognostic factor for poor survival. FRZB was also suggested as a potential candidate target for therapy.

\section{Human telomerase reverse transcriptase (hTERT)}

Telomeres are non-coding repeated DNA sequences localised at the end of each chromosome, protecting it from degradation and chromosomal fusion [23]. The length of the telomere is shortened with each cell division, limiting cellular replicative potential [24-26]. hTERT is one of two functional subunits of telomerase, a reverse transcriptase enzyme with function of maintaining telomere length. hTERT is present in most human cells but is generally repressed resulting in normal chromosomal instability and cellular senescence after a programmed amount of cell cycles [24, 27-30]. Most human cancer attain carcinogenic properties through increased hTERT activity, leading to abnormal replicative potential [31-33]. The significance of telomerase activation has been reported in a wide range of neoplasms, including gastric adenocarcinomas, lung tumours, renal-cell carcinoma and hepatocellular carcinoma [34-37]. These discoveries are coherent with studies reporting a significant correlation between hTERT and decreased OS in primary CRC $[38,39]$. In CRLM, the data of hTERT as a prognostic marker is limited, but current data identifies it as an independently significant biomarker for adverse survival $[40,41]$. Of these studies, one was found to meet the study inclusion criteria [40].

\section{p53}

The p53 tumour suppressor gene has critical functions in numerous steps of malignant cell transformation. It regulates apoptosis by controlling Bcl2 and Bax [42]. It is involved in DNA repair mechanisms and acts as a cell cycle regulator in the late G1 phase [43]. Also, it regulates TSP-1, which in turn is suggested to have angiogenetic and tumour invasive properties, as describes above [44]. The p53 gene is the most common genetic abnormality found in human cancers [45]. The expression of p53 is reported to be altered in $30-65 \%$ of primary CRC [46-56]. There have been reports of increased expression of p53 in CRLM compared to primary CRC [57]. The frequency of p53 alterations in CRLM are described as approximately $65 \%[58,59]$. Numerous studies have associated altered p53 activity with more advanced stages $[46-48,51,52,54,55]$ and unfavourable survival in primary CRC [46, 47, 49-56]. The prognostic impact of p53 in CRLM is not as obvious. One study meeting the inclusion criteria found a statistically significant correlation between p53 expression and survival [59]. The association between mutated p53 and decreased survival was confirmed by two studies, however, these studies did not 
Table 1 Independent prognostic biomarkers in resected colorectal liver metastases

\begin{tabular}{|c|c|c|c|c|c|c|}
\hline Biomarker & References & Year & $\mathrm{N}$ & Hazard ratio $(95 \% \mathrm{Cl})$ & Detection rate $^{a}$ & p-value \\
\hline \multicolumn{7}{|c|}{ Self-sufficiency in growth signals } \\
\hline Ki-67 & Ivanecz et al. [64] & 2014 & 98 & $0.82(0.68-0.98)$ & $27 / 98(28 \%)$ & 0.038 \\
\hline EGFR & Goos et al. [120] & 2014 & 323 & $1.54(1.07-2.22)^{c}$ & $121 / 323(37 \%)$ & 0.02 \\
\hline RKIP & Kim et al. [77] & 2012 & 68 & $0.19(0.09-0.45)^{c}$ & $22 / 68(32 \%)$ & 0.014 \\
\hline \multicolumn{7}{|c|}{ Insensitivity to anti-growth signals } \\
\hline p53 & Nitti et al. [59] & 1998 & 69 & $2.53(1.84-3.22)$ & $44 / 69(64 \%)$ & 0.008 \\
\hline \multicolumn{7}{|c|}{ Evading programmed cell death } \\
\hline TRX-1 & Noike et al. [142] & 2008 & 84 & $0.41(0.24-0.71)$ & $37 / 84(44 \%)$ & 0.002 \\
\hline FAS/CD95 & Onodera et al. [191] & 2005 & 85 & $3.254(1.00-10.49)$ & $30 / 85(35 \%)$ & 0.048 \\
\hline \multicolumn{7}{|c|}{ Limitless replicative potential } \\
\hline hTERT & Dômont et al. [40] & 2005 & 201 & $2.03(1.46-2.82)$ & $86 / 201(43 \%)$ & $<0.001$ \\
\hline \multicolumn{7}{|l|}{ Sustained angiogenesis } \\
\hline \multirow[t]{2}{*}{ CD34 } & Miyagawa et al. [131] & 2002 & 71 & $2.46(1.13-5.37)$ & $38 / 71(54 \%)$ & 0.023 \\
\hline & Nanashima et al. [132] & 2009 & 139 & $2.71(1.15-6.42)$ & 69/139 (50\%) & 0.023 \\
\hline PTGS2/COX-2 & Goos et al. [120] & 2014 & 351 & $1.59(1.14-2.26)^{c}$ & $85 / 351(24 \%)$ & 0.01 \\
\hline VEGFA & Goos et al. [198] & 2016 & 335 & $1.50(1.066-2.111)^{c}$ & $101 / 335(30 \%)$ & 0.02 \\
\hline \multicolumn{7}{|c|}{ Activating invasion and metastasis } \\
\hline \multirow[t]{2}{*}{ TSP-1 } & Sutton et al. [159] & 2005 & 182 & $1.82(1.00-3.10)$ & $45 / 182(25 \%)$ & 0.01 \\
\hline & Teraoku et al. [160] & 2016 & 94 & $0.38(0.12-0.99)^{c}$ & $35 / 94(63 \%)$ & $<0.05$ \\
\hline CAV-1 & Neofytou et al. [156] & 2017 & 108 & $0.40(0.21-0.78)^{c}$ & $61 / 108(56 \%)$ & 0.007 \\
\hline KISS1 & Zhu et al. [172] & 2015 & 55 & $0.20(0.05-0.91)$ & 19/55 (35\%) & 0.037 \\
\hline FRZB & Shen et al. [21] & 2015 & 136 & $2.552(1.86-3.64)$ & $89 / 136(65 \%)$ & $<0.001$ \\
\hline \multicolumn{7}{|l|}{ Deregulated metabolism } \\
\hline $\begin{array}{c}\text { Glucose transporter } 1 \\
\text { (GLUT1/SLC2A1) }\end{array}$ & Goos et al. [198] & 2016 & 350 & $0.65(0.51-0.863)^{c}$ & $179 / 350(51 \%)$ & $<0.01$ \\
\hline \multicolumn{7}{|c|}{ Immune evasion/suppression } \\
\hline $\mathrm{MHC}^{\mathrm{hi}} \mathrm{CD} 3^{\mathrm{hi}}$ & Turcotte et al. [213] & 2014 & 154 & $0.36(0.20-0.67)$ & $31 / 154(20 \%)$ & 0.001 \\
\hline $\mathrm{CD} 3+\mathrm{CD} 8$ & Wang et al. [212] & 2018 & 249 & $0.69(0.59-0.80)$ & $90 / 249(36 \%)$ & $<0.001$ \\
\hline \multirow[t]{2}{*}{ CD45RO } & Brunner et al. [211] & 2014 & $201^{\mathrm{b}}$ & $0.46(0.28-0.73)^{c}$ & 155/201 (77\%) & 0.001 \\
\hline & & 2014 & $201^{\mathrm{b}}$ & $0.25(0.10-0.64)^{c}$ & 155/201 (77\%) & 0.004 \\
\hline plgR & Liu et al. [179] & 2014 & 136 & $2.673(1.87-3.76)$ & $86 / 136(63 \%)$ & $<0.001$ \\
\hline CD83 & Miyagawa et al. [210] & 2004 & 70 & $0.42(0.23-0.76)^{c}$ & $44 / 70(63 \%)$ & 0.004 \\
\hline Tryptase & Suzuki et al. [209] & 2015 & 135 & $17.3(4.80-62)$ & $73 / 135(54 \%)$ & $<0.01$ \\
\hline CD68 & Miyagawa et al. [131] & 2002 & 71 & $2.127(1.01-4.50)$ & $36 / 71(51 \%)$ & 0.049 \\
\hline \multicolumn{7}{|l|}{ Genome instability } \\
\hline Aurora kinase A & Goos et al. [109] & 2013 & 343 & $1.66(1.08-2.54)^{c}$ & $115 / 243(34 \%)$ & 0.02 \\
\hline \multicolumn{7}{|l|}{ Other markers } \\
\hline CD133 & Yamamoto et al. [91] & 2014 & 103 & $0.320(0.13-0.81)$ & 46/103 (45\%) & 0.016 \\
\hline APOBEC3G & Lan et al. [185] & 2014 & 136 & $2.582(1.83-3.63)$ & $91 / 136(67 \%)$ & $<0.001$ \\
\hline CDX2 & Shigematsu et al. [217] & 2018 & 396 & $0.415(0.26-0.66)$ & $360 / 396$ (91\%) & $<0.001$ \\
\hline
\end{tabular}

meet the inclusion criteria for this review as other statistical methods were applied [47, 60]. In contrast, several studies investigating the impact of p53 expression on survival found no significant correlation [61-65]. As for the TP53 gene in CRLM, reports of both significant associations with survival [66-68] and no associations $[69,70]$ have been presented in studies using other methods than IHC. 


\section{Raf-1 kinase inhibitory protein (RKIP)}

RKIP contributes to preserving cells from malignant transformation. It inhibits Raf-1 kinase, an activator of the MAPK signalling pathway which is shown to have an important part in cancer progression [71, 72]. There is also evidence that the MAPK signalling pathway can dysregulate the cell cycle, induce overexpression of VEGF and enable cell mobility through activation of matrix metalloproteinases [73]. In several types of cancer, including primary CRC, reduced expression of RKIP has been associated with advanced cancer stage, metastatic spread and poor survival [74-76]. In primary CRC, RKIP expression has been identified as an independent prognostic risk factor for poor survival [74, 75]. As for resected CRLM, available data demonstrates RKIP as an independent prognostic biomarker for OS [77]. Approximately one-third of CRLM lesions are positive for RKIP [77]. Lastly, RKIP has been suggested to potentiate apoptosis induced by chemotherapy and radiotherapy $[78,79]$.

\section{Ki-67}

KI-67 is an established marker for cellular proliferation [80]. It is absent in quiescent cells (g0 phase) but is present in cell nuclei during interphase and chromosomes during mitosis $[81,82]$. The expression is increased through progression of synthesis phase of the cell cycle [83]. In primary CRC, an association between proliferation and tumour aggressiveness has been displayed [84]. In CRLM, $28-62 \%$ of tumours have been estimated as ki-67 overexpressed [64, 85]. Several studies have estimated survival rates in CRLM with proliferation through KI-67 expression. Most data suggest KI-67 overexpression to be of negative impact on survival in patients undergoing resection of CRLM [41, 85-87]. Contrary to this, one study presented an inverse consequence of ki-67 overexpression [64].

\section{Cd133}

Analysis of CD133 is an established method for identifying cancer stem cells, and is currently the most frequently used marker in analyses of human cancers [88]. It is believed that CD133 organizes plasma membrane topology, yet the exact mechanism of action remains unknown [89]. However, more is known of the clinical impact of CD133 status. Expression of CD133 has shown to be of importance in many malignancies, among them primary CRC and CRLM [90, 91]. Lack of CD133 expression was identified as an independent marker for decreased OS after resection of CRLM [91]. One study found an insignificant trend towards CD133-expression and decreased OS after liver resection, although a significant association between CD133 status on disease-free survival was found [92]. Approximately $60 \%$ of CRLM lesions have been found to stain positive for CD133 [91]. Furthermore, CD133 is thought to be predictive of chemotherapy response, as expression intensity has been linked to drug resistance [93]. Clinical studies in breast cancer have presented supporting evidence that CD133 has a function in therapy resistance [94], but no studies were found to have presented data of such an investigation in CRLM.

\section{Aurora kinase A (AURKA)}

AURKA regulates the cell cycle by regulating chromosome segregation [95]. The AURKA gene is located on a chromosomal region that is often genetically disrupted during primary CRC development and is associated with malign features and poor prognosis [96-102]. When mutated, cell viability, chromosomal stability, growth and invasion is altered [103-107]. Also, evidence suggests that ARUKA mutation initiates, rather than follows these malignant processes $[105,108]$. In resected CRLM, ARUKA protein expression has been displayed as an independent prognostic marker for OS [109], which is coherent with previous data that correlates AURKA status to survival in primary CRC $[110,111]$. A study showed displayed that AURKA status is concordant in approximately $63 \%$ of primary CRC-CRLM pairs [109].

\section{Epidermal growth factor receptor (EGFR)}

EGFR is a receptor known to mediate proliferation and angiogenesis. It acts by acting the MAPK pathway, which is one of the most understood signalling pathways in human cells [112]. Drugs aimed specifically for EGFR have become part of standardised treatment in numerous mutation positive cancers, and is today a included in routine drug regimen in primary CRC [113]. EGFR has an advanced interplay with COX-2, which also functions as a target for therapy. EGFR initiates COX-2 upregulation and COX-2 can potentiate EGFR activation [114-116]. COX-2 inhibitors have found to be a treatment option in anti-EGFR resistant cancers of metastatic CRC [117119]. In a large patient cohort, EGFR expression has been identified as an independent marker for OS in patients with resected CRLM [120]. The worsening impact of EGFR seems to be of more importance in patients who did not receive chemotherapy. It was therefore suggested that EGFR is one of the targets of commonly used chemotherapy regimen such as 5-FU. Current data suggests that EGFR is an independent prognostic biomarker for survival in resected CRLM [120], however, the optimal use of anti-EGFR agents in treatment of patients with CRLM is not yet concluded. Furthermore, data shows that EGFR status in primary CRC cannot predict EGFR status in CRLM [120-122]. 


\section{Cox-2/ptgs2}

PTGS-2, also known as COX-2, is one of two cyclooxygenases, converting arachidonic acid to prostaglandin H2. It also promotes PGE2 production, which in turn upregulates cell growth in neoplastic cells [123]. COX-2 inhibitors such as aspirin have been associated with increased survival following resection of primary CRC and decreased incidence of primary CRC overall [119, 124]. As previously described, COX-2 signalling is closely related to EGFR upregulation. In similarity to EGFR, COX-2 overexpression has been found as an independent risk factor for decreased survival in CRLM patients after surgery, especially within patients who did not receive chemotherapy [120]. COX-2 expression is concordant between primary CRC and CRLM $[120,125,126]$.

\section{Cd34}

CD34 is a frequently used marker for quantification of microvessel density in tumour tissue. Tumour angiogenesis is a fundamental attribute in supporting tumour growth and a hallmark of cancer [17]. The significance of microvessel density in in primary CRC has not been clear. Correlation between a high microvessel density and a poor prognosis has been observed in several studies [127-129]. Contraindicatory, the opposite has also been shown [130]. Two articles have found a correlation between increased staining intensity of CD34 and decreased OS in resected CRLM [131, 132]. Another study found that microvessel density decreases in resected CRLM with standard neoadjuvant chemotherapy [133]. CRLM lesions have been found to have a higher mean microvessel density compared to primary lesions [127]. A meta-analysis was conducted on provided survival data for CD34, which is presented as a forest plot (Fig. 2).

\section{Thioredoxin-1 (Trx-1)}

Thioredoxins are a group of redox proteins that are crucial for human life [134, 135]. Redox activity has been shown as a regulating factor for cellular induction apoptosis and angiogenesis [136]. Current data suggests that Trx-1 levels are increased within cancer cells driven by persistent oxidative stress [137]. Expression of redox proteins is a vital attribute for cancer cells for survival in environments with high oxidative stress [137-139]. Overexpression of Trx-1 has been displayed in numerous forms of human cancer tissue and cancer cell lines, including primary $\mathrm{CRC}$, lymph node metastases from primary CRC and CRLM [140, 141]. Almost 45\% of CRLM overexpress Trx-1 [142]. A study presented a significant concordance in staining intensity of Trx-1 between primary CRC and CRLM [142]. High levels of $\operatorname{Trx}-1$ has been associated with decreased survival in primary CRC [141]. In resected CRLM, staining intensity of Trx- 1 was found to be an independent prognostic factor for decreased OS by multivariate analysis [142]. Additionally, evidence shows that redox status has a part in cisplatin resistance, a common chemotherapy agent often used in CRLM treatment $[143,144]$.

\section{Caveolin-1 (CAV-1)}

Awareness of tumour microenviroment as a central component in carcinogenic properties has increased. Interplay between malignant cells and tumour stroma has been recognised as a key component of malignant transformation [145]. One of the most investigated stromal biomarkers is Caveolin-1, a scaffolding protein shown to have a prognostic significance in numerous cancers [146-152], among them primary CRC [152]. Decreased expression of Caveolin-1 has been identified as a main cause of how malignant cells are provided with nutrients [153-155]. One study was found to investigate the role of CAV-1 in survival after resection of CRLM [156]. This study demonstrated decreased stromal CAV1 staining intensity to be a significant biomarker for decreased overall survival by multivariate analysis. A total of $35 \%$ of CRLM cells displayed weak CAV1 expression.

\section{Thrombospondin-1 (TSP-1)}

The exact mechanism of TSP-1 in carcinogenesis remains uncertain. However, many potential functions of have been studied such as thrombocyte aggregation, tissue regeneration, regulation of protease activity and cellular activities such as adhesion, motility, and growth. One

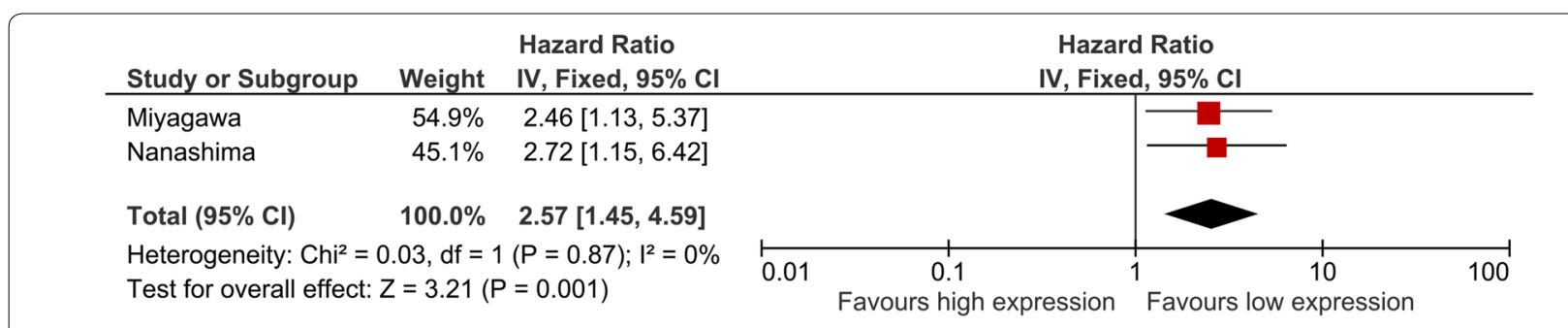

Fig. 2 Forest plot of association between CD34 expression and survival after resection of CRLM. A fixed-effect model was used for meta-analysis 
study suggested that TSP-1 has both pro- and antiangiogenic properties [157]. Another study showed that cell motility and migration is stimulated by TSP-1 via chemotaxis response [158]. Evidence of TSP-1 as a significant independent marker for OS in CRLM have been presented [159, 160]. Both studies presented significant results, however, one of them found an association between adverse surgical outcome and decreased cytoplasmic TSP-1 [160] and the other one increased stromal TSP-1 to adverse outcome [159]. Interestingly, decreased cytoplasmic expression has been correlated with poor prognosis in cervical [161], lung [162] and breast [163] cancer whilst strong stromal expression has been correlated with poor prognosis in melanoma [164], intraductal papillary mucinous neoplasms [165] and pancreatic carcinoma [166]. Possibly, TSP has different modes of action and a varying significance according to its location. The survival data of TSP-1 was pooled in a meta-analysis (Fig. 3). The different modes of action depending on location of TSP-1 should be noted when interpreting the results presented in the forest plot.

\section{Kisspeptin 1 (KISS1)}

KISS1 is an established tumour suppressor, discovered to be absent in metastatic cells but present in non-metastatic cells [167]. Acquirement of metastatic potential through KISS1 activity has been identified as a central feature in a variety of cancers, including primary CRC [168-171]. Expression of KISS1 has also been correlated with poor survival in human cancers, however, expression patterns differ between different types of malignancies [168-171]. In primary CRC, reduced expression of KISS1 has been suggested as an independent factor for decreased survival and metastatic spread [170]. In CRLM, the impact of low KISS1 expression have been found to be a significant biomarker for decreased OS [172]. The same study found KISS1 expression to be lower in CRLM than in primary lesion. A significant correlation between KISS1 in CRLM and lymphatic spread was also observed.

\section{Polymeric immunoglobulin receptor (plgR)}

plgR is a transporter of immunoglobulins IgA and IgG over epithelial membranes. The expression is strongly promoted by cytokines, thus plgR has a physiologic function as a link between innate and adaptive immunity [173-176]. The clinical impact of plgR in malignant diseases is not fully understood. Increased expression has been detected in many forms of cancer, including primary CRC [177]. Increased circulating levels of plgR has been detected in CRLM [178]. In one study, plgR expression in CRLM tissue was found to be an independent predictor for survival after resection [179]. plgR was also found to indicate high risk of metastatic spread in primary CRC. Almost two-thirds of patients were found to display high staining intensity of plgR in the same study.

\section{Apobec3 g}

APOBEC3G is a regulator of protein synthesis with a central role in anti-viral host defence, especially against HIV [180-183]. Increased expression of APOBEC3G has been documented in CRLM [184]. Two of three CRLM samples has been found to be positive for APOBEC3G [185]. Evaluation of APOBEC3G staining intensity in correlation to survival have identified positive expression as an independent prognostic biomarker in resected CRLM [185]. The same study also suggests that presence of APOBEC3G is a risk factor for metastatic spread in CRLM.

\section{First apoptotic signal (FAS/CD95)}

The FAS receptor, also known as CD95, initiates downstream signalling that results in apoptosis [186]. Stimulation of FAS is one of the two pathways known to induce cellular apoptosis [187]. Resistance to apoptosis has been described as an important part of CRLM progression and other apoptotic markers have been significantly correlated with patient outcome $[47,59,60,188]$. Also, a correlation between sensitivity to apoptosis and metastatic potential has been suggested $[189,190]$. In a study where FAS/CD95 index was analysed in relation to survival after resection of CRLM, it was found to be a strong independent indicator of survival [191]. In the same study, 35\% of patients were found to stain positive for FAS.

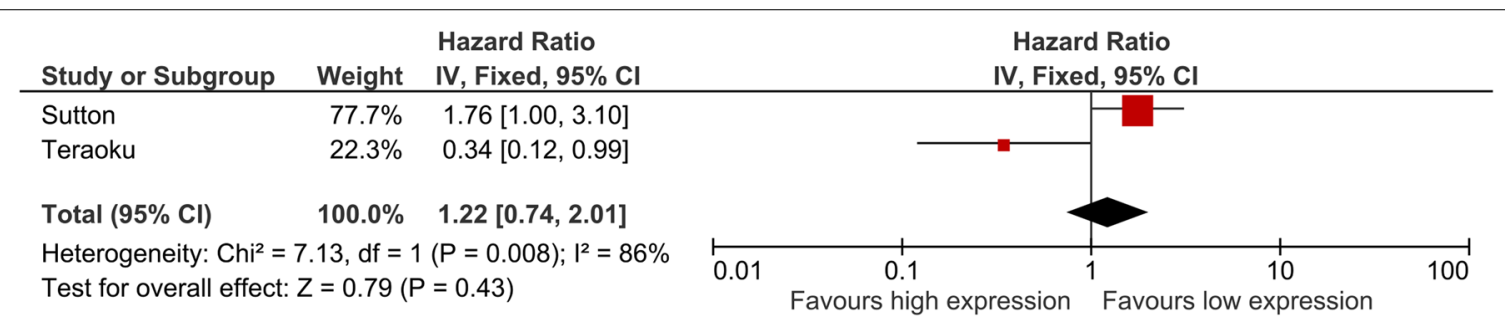

Fig. 3 Forest plot of association between TSP-1 expression and survival after resection of CRLM. A fixed-effect model was used for meta-analysis 


\section{Glucose transporter 1 (GLUT1/SLC2A1)}

In the malignant transformation of human cells, the metabolism shifts to be more dependent of the anaerobic process glycolysis. This results in an increased demand of glucose. Consequently, an upregulation of membrane glucose transporters has been associated with cancerous properties [192-195]. The expression of GLUT1, also known as SLC2A1, can potentially be regulated by local glucose levels [196]. A meta-analysis found GLUT1 expression to be of importance for survival in solid human tumours, including primary CRC [197]. In CRLM, high expression of GLUT1 was associated with good prognosis [198]. Furthermore, F-FDG PET imaging visualises glucose uptake in tissues via GLUT1 and an increased tracer uptake has been correlated to shorter survival after resection in CRLM [199]. Tumours with a higher metabolic rate can have an increased response to systemic treatment, as cells that are in active phases of the cell cycle are more susceptible to chemotherapy [200-202]. Amplified expression of GLUT-1 could therefore potentially identify patients with higher benefit of treatment.

\section{Vascular endothelial growth factor A (VEGFA)}

VEGFs are a group of proteins that stimulate growth of blood vessels. They are often overexpressed in neoplastic tumours and have been correlated to malign behaviour and decreased prognosis in various types of cancer, including primary CRC [203-205]. Immunotherapy against VEGF has improved survival in patients with primary CRC [206]. In CRLM, neoadjuvant anti-VEGF treatment has been shown to increase rate of radically resected tumours and long-term survival [207]. Increased staining of VEGFA has been proposed as an independent prognostic biomarker for worse survival after resection of CRLM (original). In combination with GLUT1 expression, patients with even worse prognosis could be identified [198]. Furthermore, VEGFA expression seemed to have the most impact on prognosis in patent groups that did not receive systemic chemotherapy (original) which could indicate that conventional chemotherapy affects VEGFA-related processes. Whether VEGFA expression can be used as a predictive marker for anti-VEGF treatment effect is yet to be determined $[198,208]$.

\section{Markers of immunologic cells and immunoscores}

Analysis of immunologic cells is in cancers is believed to play a significant role in determining tumour aggressiveness. In recent years, the volume of published data of immunologic markers and immunotherapy has remarkably increased. Presence of different cells can indicate properties such as induction of inflammation or evasion of the immune system. Data continuously provide evidence that density of different immunologic cells can function as prognostic markers after resection of CRLM. An accumulation of activated macrophages identified by PG-M1 (antibodies against CD68) was associated with shorter survival after hepatic resection [131]. A high infiltration of masts cells identified with tryptase have been correlated to worse outcome following CRLM resection [209]. A low infiltration of mature dendritic cells has been linked to worse survival [210]. Low presence of CD45RO-positive cells, a marker present in most thymocytes, T-cells and a subset of B-cells, was identified as a risk factor for shorter survival in resected CRLM [211]. Some articles have evaluated immunologic profiling by combining more than one marker to generate so called immunologic scores. A combination of CD3-CD8 (36\% detection rate) [212] and high MCH-1CD3 (20\% detection rate) [213] independently enable identification of patients with favourable survival. Lastly, it has been suggested that infiltration of immunologic cells may predict response to chemotherapy [214].

\section{Homeobox transcription factor 2 (CDX2)}

CDX2 regulates the maturation of epithelial cells in the gastrointestinal tract. Loss of CDX2 has been shown to negatively impact survival in primary CRC [215]. According to a recent study, the expression of CDX2 is highly concordant between primary CRC and CRLM, independent of whether chemotherapy has been administered prior to primary resection [216]. The prognostic impact of CDX2 expression was investigated in 396 patients with CRLM, where loss of CDX2 expression correlated to decreased survival [217]. CDX2 status has been associated with mismatch repair dysfunction, a hallmark of hereditary CRC (e.g. Lynch syndrome), which is also observed in approximately $10 \%$ of sporadic primary CRC [218]. The significance of mismatch repair proteins in CRLM remains to be further investigated.

\section{Discussion}

This is to our knowledge the first systematic review on immunohistochemical prognostic biomarkers in resected CRLM. We identified 26 independent prognostic biomarker proteins for resected CRLM (Fig. 4). Although IHC/TMA is an effective and established technique for analysing tumour markers, the lack of standardization is a problem. As highlighted by the National Cancer Institute (NCI) and European Organization for Research and Treatment of Cancer (EORTC), issues concerning variations in material (e.g. antibodies), execution (e.g. incubation time) and interpretation (e.g. cut-offs, subjectivity in scoring), are still to be resolved [16]. Additionally, there is no consensus on how survival analyses should be best performed. End points and statistical approach vary 


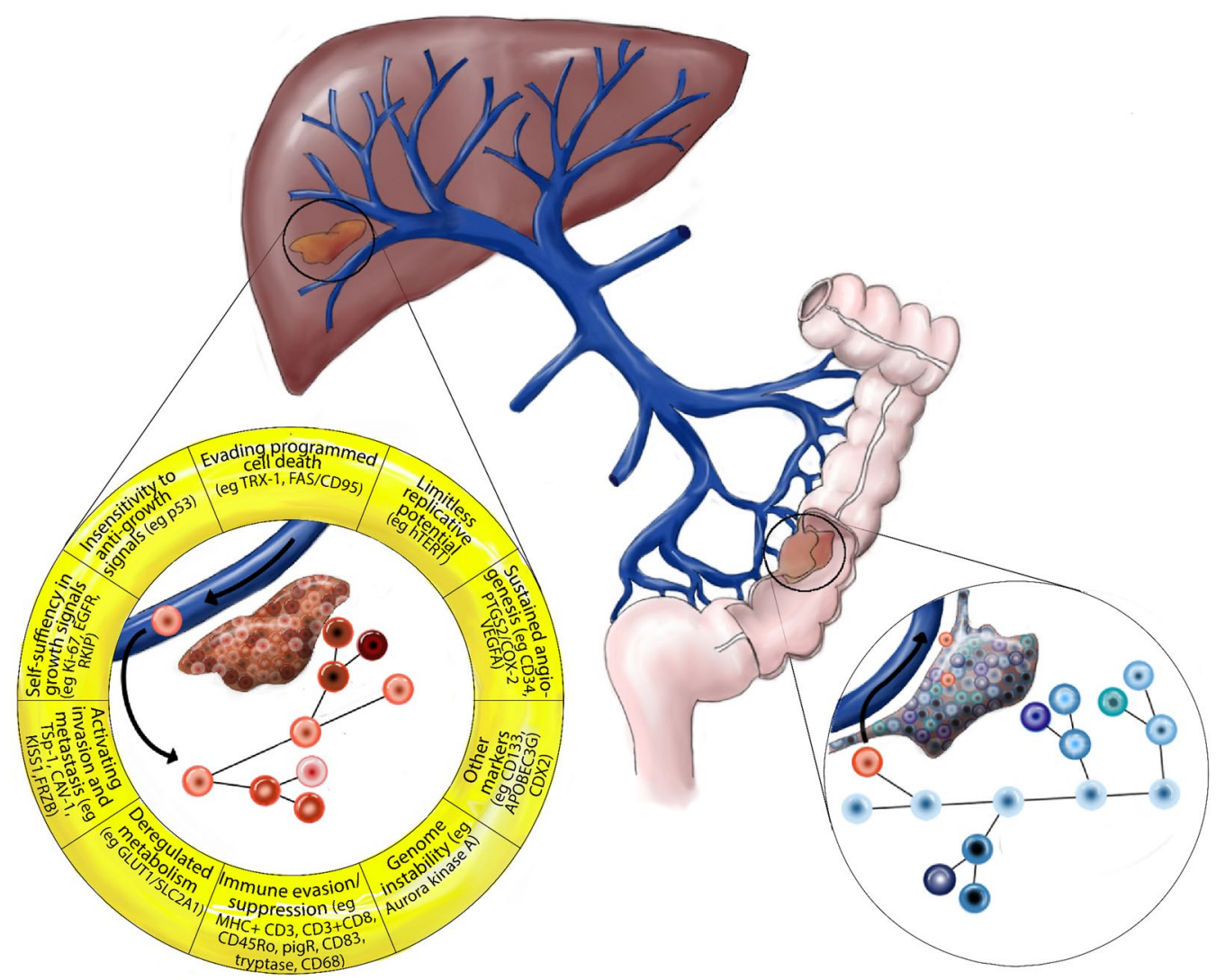

Fig. 4 Functional relevance of selected biomarker candidates

between studies and are chosen at the discretion of the authors. Altogether, this makes pooling of studies and conduction of meta-analyses difficult. Subsequently, the likelihood of using biomarkers in clinical practice is impeded by a lack of validation. This highlights the need of prospective multicentre studies with standardised protocols.

Much progress has been made in the molecular pathology of CRLM. A recent study examined the evolutionary relationship between primary CRC and metastases [219]. It was found that CRLM may arise from multiple independent seeding processes, and therefore originate from unique subclones of the primary lesion. It appears that both the primary tumour and the metastases accumulate mutations after metastatic processes have been initiated. This would mean there is heterogeneity not only between patients, but also between the primary tumour and metastasis and even between different metastases within the same patient. Therefore, there could be a diversity in invasive properties and therapy response between malignant cells within a single tumour. The accumulation of mutations in metastatic lesions can lead to discrepancy in protein expression compared to the primary tumour. This is in contrast to previous studies, where it was reported that CRLM maintains protein expression profiles when compared to corresponding primary [220, 221], which seems to be the case only for selected biomarkers. This is important to take into consideration in a future perspective when biomarkers are to be implemented in clinical practice. For example, the decision of whether a patient should receive anti-EGFR therapy for CRLM cannot solely be based on the expression of EGFR in the primary tumour if the expression levels are not corresponding to those in multiple metastases. Furthermore, the complex evolution of primary CRC to CRLM results in many possible mutation cascades, indicating that biological phenotype cannot be judged by only one biomarker. If the prognosis of CRLM is to be better understood and predicted, a panel of biomarkers is required.

Some limitations need to be considered when interpreting this study. Most articles used a retrospective study design, making a reporting and selection bias possible. There was also heterogeneity in the patient cohorts, with variations in factors such as age, gender, ethnicity, comorbidity and tumour characteristics. Methodology of 
IHC varied. Lastly, most biomarkers lacked validation in external cohorts by independent investigators.

\section{Conclusions}

We identified several independent prognostic biomarkers for resected CRLM. Larger multicentre studies are needed to investigate the real world impact of these biomarker candidates. In the future, these protein markers may potentially be included in biomarker panels to aid in clinical management, such as stratification of patients in risk groups, selection of individual treatments and development of new types of precision drugs.

\begin{abstract}
Abbreviations
AURKA: Aurora kinase A; CAV-1: Caveolin-1; CDX2: homeobox transcription factor 2; Cl: confidence interval; CRC: colorectal cancer; CRLM: colorectal liver metastases; EGFR: epidermal growth factor receptor; GLUT1/SLC2A1: glucose transporter 1; hTERT: human telomerase reverse transcriptase; IHC: immunohistochemistry; KISS1: Kisspeptin 1; OS: overall survival; RKIP: Raf-1 kinase inhibitory protein; TMA: tissue microarray; TRX-1: thioredoxin-1; TSP-1: thrombospondin-1; VEGFA: vascular endothelial growth factor A.
\end{abstract}

\section{Authors' contributions}

WT conducted the literature search and wrote the first manuscript draft. DA assisted in data interpretation and writing. RA supervised the study. All authors read and approved the final manuscript.

\section{Acknowledgements}

None.

\section{Competing interests}

The authors declare that they have no competing interests.

\section{Availability of data and materials}

All data generated or analysed during this study are included in this published article.

\section{Consent for publication}

Not applicable.

Ethics approval and consent to participate

Not applicable.

\section{Funding}

None.

\section{Publisher's Note}

Springer Nature remains neutral with regard to jurisdictional claims in published maps and institutional affiliations.

Received: 24 August 2018 Accepted: 18 December 2018 Published online: 27 December 2018

\section{References}

1. Brody H. Colorectal cancer. Nature. 2015;521(7551):S1.

2. McGuire S. Geneva, Switzerland: World Health Organization, International Agency for Research on Cancer, WHO Press, 2015. Adv Nutr. 2016;7(2):418-9.

3. Leporrier J, Maurel J, Chiche L, Bara S, Segol P, Launoy G. A populationbased study of the incidence, management and prognosis of hepatic metastases from colorectal cancer. Br J Surg. 2006;93(4):465-74.
4. PawlikTM, Scoggins CR, Zorzi D, Abdalla EK, Andres A, Eng C, Curley SA, Loyer EM, Muratore A, Mentha G, et al. Effect of surgical margin status on survival and site of recurrence after hepatic resection for colorectal metastases. Ann Surg. 2005;241(5):715-22 (discussion 722-714).

5. Bronte G, Rolfo C, Peeters M, Russo A. How to find the Ariadne's thread in the labyrinth of salvage treatment options for metastatic colorectal cancer? Expert Opin Biol Ther. 2014;14(6):743-8.

6. Fong Y, Fortner J, Sun RL, Brennan MF, Blumgart LH. Clinical score for predicting recurrence after hepatic resection for metastatic colorectal cancer: analysis of 1001 consecutive cases. Ann Surg. 1999;230(3):30918 (discussion 318-321).

7. Ivanecz A, Potrc S, Horvat M, Jagric T, Gadzijev E. The validity of clinical risk score for patients undergoing liver resection for colorectal metastases. Hepatogastroenterology. 2009;56(94-95):1452-8.

8. Reissfelder C, Rahbari NN, Koch M, Ulrich A, Pfeilschifter I, Waltert A, Muller SA, Schemmer P, Buchler MW, Weitz J. Validation of prognostic scoring systems for patients undergoing resection of colorectal cancer liver metastases. Ann Surg Oncol. 2009;16(12):3279-88.

9. Spelt L, Andersson B, Nilsson J, Andersson R. Prognostic models for outcome following liver resection for colorectal cancer metastases: a systematic review. Eur J Surg Oncol. 2012;38(1):16-24.

10. Fearon $E R$, Vogelstein B. A genetic model for colorectal tumorigenesis. Cell. 1990;61(5):759-67.

11. Smith G, Carey FA, Beattie J, Wilkie MJ, Lightfoot TJ, Coxhead J, Garner RC, Steele RJ, Wolf CR. Mutations in APC, Kirsten-ras, and p53-alternative genetic pathways to colorectal cancer. Proc Natl Acad Sci U S A. 2002;99(14):9433-8.

12. Olschwang S, Hamelin R, Laurent-Puig P, Thuille B, De Rycke Y, Li YJ, Muzeau F, Girodet J, Salmon RJ, Thomas G. Alternative genetic pathways in colorectal carcinogenesis. Proc Natl Acad Sci U S A. 1997:94(22):12122-7.

13. Tomlinson I, llyas M, Johnson V, Davies A, Clark G, Talbot I, Bodmer W. A comparison of the genetic pathways involved in the pathogenesis of three types of colorectal cancer. J Pathol. 1998;184(2):148-52.

14. Hird RB, Chang A, Cimmino V, Diehl K, Sabel M, Kleer C, Helvie M, Schott A, Young J, Hayes D, et al. Impact of estrogen receptor expression and other clinicopathologic features on tamoxifen use in ductal carcinoma in situ. Cancer. 2006;106(10):2113-8.

15. Moher D, Liberati A, Tetzlaff J, Altman DG. Preferred reporting items for systematic reviews and meta-analyses: the PRISMA statement. PLoS Med. 2009;6(7):e1000097.

16. McShane LM, Altman DG, Sauerbrei W, Taube SE, Gion M, Clark GM. Statistics Subcommittee of the NCIEWGoCD: rEporting recommendations for tumour MARKer prognostic studies (REMARK). Br J Cancer. 2005;93(4):387-91.

17. Hanahan D, Weinberg RA. Hallmarks of cancer: the next generation. Cell. 2011;144(5):646-74.

18. Klaus A, Birchmeier W. Wnt signalling and its impact on development and cancer. Nat Rev Cancer. 2008;8:387.

19. Lories RJ, Peeters J, Bakker A, Tylzanowski P, Derese I, Schrooten J, Thomas JT, Luyten FP. Articular cartilage and biomechanical properties of the long bones in Frzb-knockout mice. Arthritis Rheum. 2007:56(12):4095-103.

20. Hirata H, Hinoda Y, Ueno K, Majid S, Saini S, Dahiya R. Role of secreted frizzled-related protein 3 in human renal cell carcinoma. Cancer Res. 2010;70(5):1896-905.

21. Shen Y, Zhang F, Lan H, Chen $K$, Zhang $Q$, Xie G, Teng L, Jin K. FRZB upregulation is correlated with hepatic metastasis and poor prognosis in colon carcinoma patients with hepatic metastasis. Int J Clin Exp Pathol. 2015;8(4):4083-90.

22. Lan H, Jin K, Xie B, Han N, Cui B, Cao F, Teng L. Heterogeneity between primary colon carcinoma and paired lymphatic and hepatic metastases Mol Med Rep. 2012;6(5):1057-68.

23. Murnane JP. Telomere dysfunction and chromosome instability. Mutat Res. 2012;730(1-2):28-36.

24. Blackburn EH. Structure and function of telomeres. Nature. 1991;350(6319):569-73.

25. Greider CW. Telomeres. Curr Opin Cell Biol. 1991;3(3):444-51.

26. Moyzis RK, Buckingham JM, Cram LS, Dani M, Deaven LL, Jones MD, Meyne J, Ratliff RL, Wu JR. A highly conserved repetitive DNA sequence, 
(TTAGGG)n, present at the telomeres of human chromosomes. Proc Natl Acad Sci U S A. 1988;85(18):6622-6.

27. Harvey JH, Smith FP, Schein PS. 5-Fluorouracil, mitomycin, and doxorubicin (FAM) in carcinoma of the biliary tract. J Clin Oncol. 1984;2(11):1245-8.

28. Lindsey J, McGill NI, Lindsey LA, Green DK, Cooke HJ. In vivo loss of telomeric repeats with age in humans. Mutat Res. 1991;256(1):45-8.

29. Shore D. Telomerase and telomere-binding proteins: controlling the endgame. Trends Biochem Sci. 1997;22(7):233-5.

30. Vaziri H, Dragowska W, Allsopp RC, Thomas TE, Harley CB, Lansdorp PM. Evidence for a mitotic clock in human hematopoietic stem cells: loss of telomeric DNA with age. Proc Natl Acad Sci U S A. 1994;91 (21):9857-60.

31. Kim NW, Piatyszek MA, Prowse KR, Harley CB, West MD, Ho PL, Coviello GM, Wright WE, Weinrich SL, Shay JW. Specific association of human telomerase activity with immortal cells and cancer. Science. 1994;266(5193):2011-5.

32. Shay JW, Werbin H, Wright WE. Telomeres and telomerase in human leukemias. Leukemia. 1996;10(8):1255-61.

33. Shay JW, Wright WE. The reactivation of telomerase activity in cancer progression. Trends Genet. 1996;12(4):129-31.

34. Kyo S, Kanaya T, Takakura M, Tanaka M, Inoue M. Human telomerase reverse transcriptase as a critical determinant of telomerase activity in normal and malignant endometrial tissues. Int J Cancer. 1999;80(1):60-3.

35. Lantuejoul S, Soria JC, Moro-Sibilot D, Morat L, Veyrenc S, Lorimier P, Brichon PY, Sabatier L, Brambilla C, Brambilla E. Differential expression of telomerase reverse transcriptase (hTERT) in lung tumours. Br J Cancer. 2004;90(6):1222-9.

36. Liu YC, Chen CJ, Wu HS, Chan DC, Yu JC, Yang AH, Cheng YL, Lee SC, Harn HJ. Telomerase and c-myc expression in hepatocellular carcinomas. Eur J Surg Oncol. 2004:30(4):384-90.

37. Yoo J, Park SY, Kang SJ, Kim BK, Shim SI, Kang CS. Expression of telomerase activity, human telomerase RNA, and telomerase reverse transcriptase in gastric adenocarcinomas. Mod Pathol. 2003;16(7):700-7.

38. Shoji Y, Yoshinaga K, Inoue A, Iwasaki A, Sugihara K. Quantification of telomerase activity in sporadic colorectal carcinoma: association with tumor growth and venous invasion. Cancer. 2000;88(6):1304-9.

39. Wei R, Younes M. Immunohistochemical detection of telomerase reverse transcriptase in colorectal adenocarcinoma and benign colonic mucosa. Hum Pathol. 2002;33(7):693-6.

40. Domont J, Pawlik TM, Boige V, Rose M, Weber JC, Hoff PM, Brown TD, Zorzi D, Morat L, Pignon JP, et al. Catalytic subunit of human telomerase reverse transcriptase is an independent predictor of survival in patients undergoing curative resection of hepatic colorectal metastases: a multicenter analysis. J Clin Oncol. 2005;23(13):3086-93.

41. Smith DL, Soria JC, Morat L, Yang Q, Sabatier L, Liu DD, Nemr RA, Rashid A, Vauthey JN. Human telomerase reverse transcriptase (hTERT) and $\mathrm{Ki}-67$ are better predictors of survival than established clinical indicators in patients undergoing curative hepatic resection for colorectal metastases. Ann Surg Oncol. 2004;11 (1):45-51.

42. Miyashita T, Reed JC. Tumor suppressor p53 is a direct transcriptional activator of the human bax gene. Cell. 1995;80(2):293-9.

43. Marx J. New link found between p53 and DNA repair. Science. 1994;266(5189):1321-2.

44. Dameron KM, Volpert OV, Tainsky MA, Bouck N. Control of angiogenesis in fibroblasts by P53 regulation of thrombospondin-1. Science. 1994;265(5178):1582-4.

45. Joerger AC, Fersht AR. Structural biology of the tumor suppressor p53. Annu Rev Biochem. 2008;77:557-82.

46. Auvinen A, Isola J, Visakorpi T, Koivula T, Virtanen S, Hakama M. Overexpression of p53 and long-term survival in colon carcinoma. Br J Cancer. 1994;70(2):293-6.

47. Belluco C, Guillem JG, Kemeny N, Huang Y, Klimstra D, Berger MF, Cohen AM. p53 nuclear protein overexpression in colorectal cancer: a dominant predictor of survival in patients with advanced hepatic metastases. J Clin Oncol. 1996;14(10):2696-701.

48. Bertorelle R, Esposito G, Del Mistro A, Belluco C, Nitti D, Lise M, ChiecoBianchi L. Association of p53 gene and protein alterations with metastases in colorectal cancer. Am J Surg Pathol. 1995;19(4):463-71.

49. Diez M, Enriquez JM, Camunas J, Gonzalez A, Gutierrez A, Muguerza $J \mathrm{M}$, Ruiz A, Granell J. Prediction of recurrence in B-C stages of colorectal cancer by p53 nuclear overexpression in comparison with standard pathological features. Eur J Surg Oncol. 1995;21(6):635-9.

50. Lanza G Jr, Maestri I, Dubini A, Gafa R, Santini A, Ferretti S, Cavazzini L. p53 expression in colorectal cancer: relation to tumor type, DNA ploidy pattern and short-term survival. Am J Clin Pathol. 1996;105(5):604-12.

51. Remvikos Y, Tominaga O, Hammel P, Laurent-Puig P, Salmon RJ, Dutrillaux B, Thomas G. Increased p53 protein content of colorectal tumours correlates with poor survival. Br J Cancer. 1992;66(4):758-64.

52. Starzynska T, Bromley M, Ghosh A, Stern PL. Prognostic significance of p53 overexpression in gastric and colorectal carcinoma. Br J Cancer. 1992;66(3):558-62.

53. Tomoda H, Kakeji Y. Immunohistochemical analysis of p53 in colorectal cancer regarding clinicopathological correlation and prognostic significance. J Surg Oncol. 1995;58(2):125-8.

54. Yamaguchi A, Kurosaka Y, Fushida S, Kanno M, Yonemura Y, Miwa $\mathrm{K}$, Miyazaki I. Expression of p53 protein in colorectal cancer and its relationship to short-term prognosis. Cancer. 1992;70(12):2778-84.

55. Yamaguchi A, Nakagawara G, Kurosaka Y, Nishimura G, Yonemura Y, Miyazaki I. p53 immunoreaction in endoscopic biopsy specimens of colorectal cancer, and its prognostic significance. Br J Cancer. 1993;68(2):399-402.

56. Zeng ZS, Sarkis AS, Zhang ZF, Klimstra DS, Charytonowicz E, Guillem JG, Cordon-Cardo C, Cohen AM. p53 nuclear overexpression: an independent predictor of survival in lymph node-positive colorectal cancer patients. J Clin Oncol. 1994;12(10):2043-50.

57. Backus HHJ, Van Groeningen CJ, Vos W, Dukers DF, Bloemena E, Wouters D, Pinedo HM, Peters GJ. Differential expression of cell cycle and apoptosis related proteins in colorectal mucosa, primary colon tumours, and liver metastases. J Clin Pathol. 2002;55(3):206-11.

58. Menon AG, Tollenaar RA, van de Velde CJ, Putter H, Janssen-van Rhijn CM, Keijzer R, Fleuren GJ, Kuppen PJ. p53 and HLA class-I expression are not down-regulated in colorectal cancer liver metastases. Clin Exp Metastasis. 2004;21 (1):79-85.

59. Nitti D, Belluco C, Montesco MC, Bertorelle R, Da Pian PP, Fassina A, Ninfo V, Chieco-Bianchi L, Lise M. Nuclear p53 protein expression in resected hepatic metastases from colorectal cancer: an independent prognostic factor of survival. Eur J Cancer. 1998;34(6):851-5.

60. Tanaka K, Shimada H, Miura M, Fujii Y, Yamaguchi S, Endo I, Sekido $H$, Togo S, Ike H. Metastatic tumor doubling time: most important prehepatectomy predictor of survival and nonrecurrence of hepatic colorectal cancer metastasis. World J Surg. 2004;28(3):263-70.

61. Crowe PJ, Yang JL, Berney CR, Erskine C, Ham JM, Fisher R, Russell PJ. Genetic markers of survival and liver recurrence after resection of liver metastases from colorectal cancer. World J Surg. 2001;25(8):996-1001.

62. Gonen M, Hummer A, Zervoudakis A, Sullivan D, Fong Y, Banerjee D, Klimstra D, Cordon-Cardo C, Bertino J, Kemeny N. Thymidylate synthase expression in hepatic tumors is a predictor of survival and progression in patients with resectable metastatic colorectal cancer. J Clin Oncol. 2003;21(3):406-12.

63. Heisterkamp J, van Bommel J, Hop WC, Tilanus HW, Zondervan PE. JN IJ: P53 overexpression in colorectal metastases confined to the liver and outcome of liver resection. Hepatogastroenterology. 1999;46(30):3109-14.

64. Ivanecz A, Kavalar R, Palfy M, Pivec V, Sremec M, Horvat M, Potrc S. Can we improve the clinical risk score? The prognostic value of p53, $\mathrm{Ki}-67$ and thymidylate synthase in patients undergoing radical resection of colorectal liver metastases. HPB (Oxford). 2014;16(3):235-42.

65. Ochiai H, Nakanishi Y, Fukasawa Y, Sato Y, Yoshimura K, Moriya Y, Kanai Y, Watanabe M, Hasegawa H, Kitagawa Y, et al. A new formula for predicting liver metastasis in patients with colorectal cancer: immunohistochemical analysis of a large series of 439 surgically resected cases. Oncology. 2008;75(1-2):32-41.

66. Etienne MC, Chazal M, Laurent-Puig P, Magne N, Rosty C, Formento $J$, Francoual M, Formento P, Renee N, Chamorey E, et al. Prognostic value of tumoral thymidylate synthase and p53 in metastatic colorectal cancer patients receiving fluorouracil-based chemotherapy: phenotypic and genotypic analyses. J Clin Oncol. 2002;20(12):2832-43.

67. Mollevi DG, Serrano T, Ginesta MM, Valls J, Torras J, Navarro M, Ramos E, Germa JR, Jaurrieta E, Moreno V, et al. Mutations in TP53 are a 
prognostic factor in colorectal hepatic metastases undergoing surgical resection. Carcinogenesis. 2007;28(6):1241-6.

68. Yang Y, Forslund A, Remotti H, Lonnroth C, Andersson M, Brevinge $H$, Svanberg E, Lindner P, Hafstrom L, Naredi P, et al. P53 mutations in primary tumors and subsequent liver metastases are related to survival in patients with colorectal carcinoma who undergo liver resection. Cancer. 2001;91(4):727-36.

69. de Jong KP, Gouw AS, Peeters PM, Bulthuis M, Menkema L, Porte RJ, Slooff MJ, van Goor H, van den Berg A. P53 mutation analysis of colorectal liver metastases: relation to actual survival, angiogenic status, and p53 overexpression. Clin Cancer Res. 2005;11(11):4067-73.

70. Saw RP, Koorey D, Painter D, Gallagher PJ, Solomon MJ. p53, DCC and thymidylate synthase as predictors of survival after resection of hepatic metastases from colorectal cancer. Br J Surg. 2002;89(11):1409-15.

71. Wang X, Wang Q, Hu W, Evers BM. Regulation of phorbol ester-mediated TRAF1 induction in human colon cancer cells through a PKC/RAF/ ERK/NF-kappaB-dependent pathway. Oncogene. 2004;23(10):1885-95.

72. Yeung K, Seitz T, Li S, Janosch P, McFerran B, Kaiser C, Fee F, Katsanakis KD, Rose DW, Mischak H, et al. Suppression of Raf-1 kinase activity and MAP kinase signalling by RKIP. Nature. 1999;401(6749):173-7.

73. Fang JY, Richardson BC. The MAPK signalling pathways and colorectal cancer. Lancet Oncol. 2005;6(5):322-7.

74. Al-Mulla F, Hagan S, Behbehani Al, Bitar MS, George SS, Going JJ, Garcia JJ, Scott L, Fyfe N, Murray Gl, et al. Raf kinase inhibitor protein expression in a survival analysis of colorectal cancer patients. J Clin Oncol. 2006;24(36):5672-9.

75. Minoo P, Zlobec I, Baker K, Tornillo L, Terracciano L, Jass JR, Lugli A. Loss of raf-1 kinase inhibitor protein expression is associated with tumor progression and metastasis in colorectal cancer. Am J Clin Pathol. 2007;127(5):820-7.

76. Schuierer MM, Bataille F, Weiss TS, Hellerbrand C, Bosserhoff AK. Raf kinase inhibitor protein is downregulated in hepatocellular carcinoma. Oncol Rep. 2006;16(3):451-6.

77. Kim HS, Park SJ, Lee KY, Park YK, Kim YW. Reduced Raf-1 kinase inhibitor protein expression predicts less favorable outcomes in patients with hepatic colorectal metastasis. Oncol Rep. 2012;28(1):161-71.

78. Chatterjee D, Bai Y, Wang Z, Beach S, Mott S, Roy R, Braastad C, Sun Y, Mukhopadhyay A, Aggarwal BB, et al. RKIP sensitizes prostate and breast cancer cells to drug-induced apoptosis. J Biol Chem. 2004:279(17):17515-23.

79. Woods Ignatoski KM, Grewal NK, Markwart SM, Vellaichamy A, Chinnaiyan AM, Yeung K, Ray ME, Keller ET. Loss of Raf kinase inhibitory protein induces radioresistance in prostate cancer. Int J Radiat Oncol Biol Phys. 2008;72(1):153-60.

80. Scholzen T, Gerdes J. The Ki-67 protein: from the known and the unknown. J Cell Physiol. 2000;182(3):311-22.

81. Bruno S, Darzynkiewicz Z. Cell cycle dependent expression and stability of the nuclear protein detected by Ki-67 antibody in $\mathrm{HL}-60$ cells. Cell Prolif. 1992;25(1):31-40.

82. Cuylen S, Blaukopf C, Politi AZ, Muller-Reichert T, Neumann B, Poser I, Ellenberg J, Hyman AA, Gerlich DW. Ki-67 acts as a biological surfactant to disperse mitotic chromosomes. Nature. 2016;535(7611):308-12.

83. Darzynkiewicz Z, Zhao H, Zhang S, Lee MY, Lee EY, Zhang Z. Initiation and termination of DNA replication during $S$ phase in relation to cyclins D1, E and A, p21WAF1, Cdt1 and the p12 subunit of DNA polymerase delta revealed in individual cells by cytometry. Oncotarget. 2015;6(14):11735-50.

84. Anjomshoaa A, Nasri S, Humar B, McCall JL, Chatterjee A, Yoon HS, McNoe L, Black MA, Reeve AE. Slow proliferation as a biological feature of colorectal cancer metastasis. Br J Cancer. 2009;101(5):822-8.

85. Nash GM, Gimbel M, Shia J, Nathanson DR, Ndubuisi MI, Zeng ZS, Kemeny N, Paty PB. KRAS mutation correlates with accelerated metastatic progression in patients with colorectal liver metastases. Ann Surg Oncol. 2010;17(2):572-8

86. Petrowsky H, Sturm I, Graubitz O, Kooby DA, Staib-Sebler E, Gog C, Kohne $\mathrm{CH}$, Hillebrand T, Daniel PT, Fong Y, et al. Relevance of Ki-67 antigen expression and K-ras mutation in colorectal liver metastases. Eur J Surg Oncol. 2001;27(1):80-7.

87. Weber JC, Nakano H, Bachellier P, Oussoultzoglou E, Inoue K, Shimura $\mathrm{H}$, Wolf $\mathrm{P}$, Chenard-Neu MP, Jaeck D. Is a proliferation index of cancer cells a reliable prognostic factor after hepatectomy in patients with colorectal liver metastases? Am J Surg. 2001;182(1):81-8.

88. Kim YS, Kaidina AM, Chiang JH, Yarygin KN, Lupatov AY. Molecular markers of cancer stem cells verified in vivo. Biomed Khim. 2016;62(3):228-38.

89. Irollo E, Pirozzi G. CD133: to be or not to be, is this the real question? Am J Transl Res. 2013;5(6):563-81.

90. Horst D, Kriegl L, Engel J, Kirchner T, Jung A. CD133 expression is an independent prognostic marker for low survival in colorectal cancer. $\mathrm{Br}$ J Cancer. 2008;99(8):1285-9.

91. Yamamoto S, Tanaka K, Takeda K, Akiyama H, Ichikawa Y, Nagashima Y, Endo I. Patients with CD133-negative colorectal liver metastasis have a poor prognosis after hepatectomy. Ann Surg Oncol. 2014;21(6):1853-61.

92. Spelt L, Sasor A, Ansari D, Hilmersson KS, Andersson R. The prognostic role of cancer stem cell markers for long-term outcome after resection of colonic liver metastases. Anticancer Res. 2018;38(1):313-20.

93. Reya T, Morrison SJ, Clarke MF, Weissman IL. Stem cells, cancer, and cancer stem cells. Nature. 2001;414(6859):105-11.

94. Nadal R, Ortega FG, Salido M, Lorente JA, Rodriguez-Rivera M, DelgadoRodriguez M, Macia M, Fernandez A, Corominas JM, Garcia-Puche JL, et al. CD133 expression in circulating tumor cells from breast cancer patients: potential role in resistance to chemotherapy. Int J Cancer. 2013;133(10):2398-407.

95. Lens SM, Voest EE, Medema RH. Shared and separate functions of polo-like kinases and aurora kinases in cancer. Nat Rev Cancer. 2010;10(12):825-41.

96. Aust DE, Muders M, Kohler A, Schmidt M, Diebold J, Muller C, Lohrs $\mathrm{U}$, Waldman FM, Baretton GB. Prognostic relevance of 20q13 gains in sporadic colorectal cancers: a FISH analysis. Scand J Gastroenterol. 2004;39(8):766-72.

97. Bischoff JR, Anderson L, Zhu Y, Mossie K, Ng L, Souza B, Schryver B, Flanagan P, Clairvoyant F, Ginther C, et al. A homologue of Drosophila aurora kinase is oncogenic and amplified in human colorectal cancers. EMBO J. 1998;17(11):3052-65.

98. Carvalho B, Postma C, Mongera S, Hopmans E, Diskin S, van de Wiel MA, van Criekinge W, Thas O, Matthai A, Cuesta MA, et al. Multiple putative oncogenes at the chromosome $20 \mathrm{q}$ amplicon contribute to colorectal adenoma to carcinoma progression. Gut. 2009:58(1):79-89.

99. Hermsen M, Postma C, Baak J, Weiss M, Rapallo A, Sciutto A, Roemen G, Arends JW, Williams R, Giaretti W, et al. Colorectal adenoma to carcinoma progression follows multiple pathways of chromosomal instability. Gastroenterology. 2002;123(4):1109-19.

100. Nakao K, Mehta KR, Fridlyand J, Moore DH, Jain AN, Lafuente A, Wiencke JW, Terdiman JP, Waldman FM. High-resolution analysis of DNA copy number alterations in colorectal cancer by array-based comparative genomic hybridization. Carcinogenesis. 2004;25(8):1345-57.

101. Postma C, Terwischa S, Hermsen MA, van der Sijp JR, Meijer GA. Gain of chromosome $20 \mathrm{q}$ is an indicator of poor prognosis in colorectal cancer. Cell Oncol. 2007;29(1):73-5.

102. Sillars-Hardebol AH, Carvalho B, de Wit M, Postma C, Delis-van Diemen PM, Mongera S, YIstra B, van de Wiel MA, Meijer GA, Fijneman RJ. Identification of key genes for carcinogenic pathways associated with colorectal adenoma-to-carcinoma progression. Tumour Biol. 2010:31(2):89-96.

103. Lee HH, Zhu Y, Govindasamy KM, Gopalan G. Downregulation of Aurora-A overrides estrogen-mediated growth and chemoresistance in breast cancer cells. Endocr Relat Cancer. 2008;15(3):765-75.

104. Moore MJ, Wang Q, Kennedy CJ, Silver PA. An alternative splicing network links cell-cycle control to apoptosis. Cell. 2010;142(4):625-36.

105. Sillars-Hardebol AH, Carvalho B, Tijssen M, Belien JA, de Wit M, Delis-van Diemen PM, Ponten F, van de Wiel MA, Fijneman RJ, Meijer GA. TPX2 and AURKA promote $20 \mathrm{q}$ amplicon-driven colorectal adenoma to carcinoma progression. Gut. 2012;61(11):1568-75.

106. Wang X, Dong L, Xie J, Tong T, Zhan Q. Stable knockdown of Aurora-A by vector-based RNA interference in human esophageal squamous cell carcinoma cell line inhibits tumor cell proliferation, invasion and enhances apoptosis. Cancer Biol Ther. 2009;8(19):1852-9.

107. Zhang H, Chen X, Liu B, Zhou L. Effects of stable knockdown of Aurora kinase A on proliferation, migration, chromosomal instability, and 
expression of focal adhesion kinase and matrix metalloproteinase-2 in HEp-2 cells. Mol Cell Biochem. 2011;357(1-2):95-106.

108. Baba Y, Nosho K, Shima K, Irahara N, Kure S, Toyoda S, Kirkner GJ, Goel A, Fuchs CS, Ogino S. Aurora-A expression is independently associated with chromosomal instability in colorectal cancer. Neoplasia. 2009;11(5):418-25.

109. Goos JA, Coupe VM, Diosdado B, Delis-Van Diemen PM, Karga C, Belien JA, Carvalho B, van den Tol MP, Verheul HM, Geldof AA, et al. Aurora kinase A (AURKA) expression in colorectal cancer liver metastasis is associated with poor prognosis. Br J Cancer. 2013;109(9):2445-52.

110. Belt EJ, Brosens RP, Delis-van Diemen PM, Bril H, Tijssen M, van Essen DF, Heymans MW, Belien JA, Stockmann HB, Meijer S, et al. Cell cycle proteins predict recurrence in stage II and III colon cancer. Ann Surg Oncol. 2012;19(Suppl 3):S682-92.

111. Lam AK, Ong K, Ho YH. Aurora kinase expression in colorectal adenocarcinoma: correlations with clinicopathological features, p16 expression, and telomerase activity. Hum Pathol. 2008;39(4):599-604.

112. Molina JR, Adjei AA. The Ras/Raf/MAPK pathway. J Thorac Oncol. 2006;1 (1):7-9.

113. Ciardiello F, Tortora G. EGFR antagonists in cancer treatment. N Engl J Med. 2008;358(11):1160-74.

114. Buchanan FG, Wang D, Bargiacchi F, DuBois RN. Prostaglandin E2 regulates cell migration via the intracellular activation of the epidermal growth factor receptor. J Biol Chem. 2003;278(37):35451-7.

115. Coffey RJ, Hawkey CJ, Damstrup L, Graves-Deal R, Daniel VC, Dempsey PJ, Chinery R, Kirkland SC, DuBois RN, Jetton TL, et al. Epidermal growth factor receptor activation induces nuclear targeting of cyclooxygenase-2, basolateral release of prostaglandins, and mitogenesis in polarizing colon cancer cells. Proc Natl Acad Sci U S A. 1997;94(2):657-62.

116. Pai R, Soreghan B, Szabo IL, Pavelka M, Baatar D, Tarnawski AS. Prostaglandin E2 transactivates EGF receptor: a novel mechanism for promoting colon cancer growth and gastrointestinal hypertrophy. Nat Med. 2002;8(3):289-93.

117. Liao X, Lochhead P, Nishihara R, Morikawa T, Kuchiba A, Yamauchi M, Imamura Y, Qian ZR, Baba Y, Shima K, et al. Aspirin use, tumor PIK3CA mutation, and colorectal-cancer survival. N Engl J Med. 2012;367(17):1596-606.

118. Mao C, Yang ZY, Hu XF, Chen Q, Tang JL. PIK3CA exon 20 mutations as a potential biomarker for resistance to anti-EGFR monoclonal antibodies in KRAS wild-type metastatic colorectal cancer: a systematic review and meta-analysis. Ann Oncol. 2012;23(6):1518-25.

119. Tougeron D, Sha D, Manthravadi S, Sinicrope FA. Aspirin and colorectal cancer: back to the future. Clin Cancer Res. 2014;20(5):1087-94.

120. Goos JA, Hiemstra AC, Coupe VM, Diosdado B, Kooijman W, Delis-Van Diemen PM, Karga C, Belien JA, Menke-van der Houven van Oordt CW, Geldof AA, et al. Epidermal growth factor receptor (EGFR) and prostaglandin-endoperoxide synthase 2 (PTGS2) are prognostic biomarkers for patients with resected colorectal cancer liver metastases. Br J Cancer. 2014;111(4):749-55.

121. Diep CB, Kleivi K, Ribeiro FR, Teixeira MR, Lindgjaerde OC, Lothe RA. The order of genetic events associated with colorectal cancer progression inferred from meta-analysis of copy number changes. Genes Chromosomes Cancer. 2006:45(1):31-41.

122. Yarom N, Marginean C, Moyana T, Gorn-Hondermann I, Birnboim HC, Marginean H, Auer RC, Vickers M, Asmis TR, Maroun J, et al. EGFR expression variance in paired colorectal cancer primary and metastatic tumors. Cancer Biol Ther. 2010;10(5):416-21.

123. Castellone MD, Teramoto H, Williams BO, Druey KM, Gutkind JS. Prostaglandin E2 promotes colon cancer cell growth through a Gs-axin-betacatenin signaling axis. Science. 2005;310(5753):1504-10.

124. Zoratto F, Rossi L, Verrico M, Papa A, Basso E, Zullo A, Tomao L, Romiti A, Lo Russo G, Tomao S. Focus on genetic and epigenetic events of colorectal cancer pathogenesis: implications for molecular diagnosis. Tumour Biol. 2014;35(7):6195-206.

125. Attolini CS, Cheng YK, Beroukhim R, Getz G, Abdel-Wahab O, Levine RL, Mellinghoff IK, Michor F. A mathematical framework to determine the temporal sequence of somatic genetic events in cancer. Proc Natl Acad Sci U S A. 2010;107(41):17604-9.

126. Charalambous MP, Maihofner C, Bhambra U, Lightfoot T, Gooderham $\mathrm{NJ}$, Colorectal Cancer Study G. Upregulation of cyclooxygenase-2 is accompanied by increased expression of nuclear factor-kappa B and
I kappa B kinase-alpha in human colorectal cancer epithelial cells. Br J Cancer. 2003;88(10):1598-604

127. Rajaganeshan R, Prasad R, Guillou PJ, Chalmers CR, Scott N, Sarkar R, Poston G, Jayne DG. The influence of invasive growth pattern and microvessel density on prognosis in colorectal cancer and colorectal liver metastases. Br J Cancer. 2007;96(7):1112-7.

128. Tanigawa N, Amaya H, Matsumura M, Lu C, Kitaoka A, Matsuyama K, Muraoka R. Tumor angiogenesis and mode of metastasis in patients with colorectal cancer. Cancer Res. 1997;57(6):1043-6.

129. Vermeulen PB, Van den Eynden GG, Huget P, Goovaerts G, Weyler J, Lardon F, Van Marck E, Hubens G, Dirix LY. Prospective study of intratumoral microvessel density, p53 expression and survival in colorectal cancer. Br J Cancer. 1999:79(2):316-22.

130. Prall F, Gringmuth U, Nizze H, Barten M. Microvessel densities and microvascular architecture in colorectal carcinomas and their liver metastases: significant correlation of high microvessel densities with better survival. Histopathology. 2003:42(5):482-91.

131. Miyagawa S, Miwa S, Soeda J, Kobayashi A, Kawasaki S. Morphometric analysis of liver macrophages in patients with colorectal liver metastasis. Clin Exp Metastasis. 2002;19(2):119-25.

132. Nanashima A, Shibata K, Nakayama T, Tobinaga S, Araki M, Kunizaki M, Takeshita H, Hidaka S, Sawai T, Nagayasu T, et al. Clinical significance of microvessel count in patients with metastatic liver cancer originating from colorectal carcinoma. Ann Surg Oncol. 2009;16(8):2130-7.

133. Eefsen RL, Engelholm L, Willemoe GL, Van den Eynden GG, Laerum OD, Christensen IJ, Rolff HC, Hoyer-Hansen G, Osterlind K, Vainer B, et al. Microvessel density and endothelial cell proliferation levels in colorectal liver metastases from patients given neo-adjuvant cytotoxic chemotherapy and bevacizumab. Int J Cancer. 2016;138(7):1777-84.

134. Holmgren A. Thioredoxin and glutaredoxin systems. J Biol Chem. 1989:264(24):13963-6.

135. Nordberg J, Arner ES. Reactive oxygen species, antioxidants, and the mammalian thioredoxin system. Free Radic Biol Med. 2001;31(11):1287-312.

136. Circu ML, Aw TY. Reactive oxygen species, cellular redox systems, and apoptosis. Free Radic Biol Med. 2010;48(6):749-62.

137. Toyokuni S, Okamoto K, Yodoi J, Hiai H. Persistent oxidative stress in cancer. FEBS Lett. 1995;358(1):1-3.

138. Mitsui A, Hamuro J, Nakamura H, Kondo N, Ishizaki-Koizumi S, Hirakawa $\mathrm{T}$, Inoue T, Yodoi J. Overexpression of human thioredoxin in transgenic mice controls oxidative stress and life span. Antioxid Redox Signal. 2002;4(4):693-6.

139. Nakamura H, Matsuda M, Furuke K, Kitaoka Y, I wata S, Toda K, Inamoto T, Yamaoka Y, Ozawa K, Yodoi J. Adult T cell leukemia-derived factor/human thioredoxin protects endothelial F-2 cell injury caused by activated neutrophils or hydrogen peroxide. Immunol Lett. 1994;42(1-2):75-80.

140. Berggren M, Gallegos A, Gasdaska JR, Gasdaska PY, Warneke J, Powis G. Thioredoxin and thioredoxin reductase gene expression in human tumors and cell lines, and the effects of serum stimulation and hypoxia. Anticancer Res. 1996;16(6B):3459-66.

141. Raffel J, Bhattacharyya AK, Gallegos A, Cui H, Einspahr JG, Alberts DS, Powis G. Increased expression of thioredoxin-1 in human colorectal cancer is associated with decreased patient survival. J Lab Clin Med. 2003;142(1):46-51.

142. Noike T, Miwa S, Soeda J, Kobayashi A, Miyagawa S. Increased expression of thioredoxin-1, vascular endothelial growth factor, and redox factor- 1 is associated with poor prognosis in patients with liver metastasis from colorectal cancer. Hum Pathol. 2008;39(2):201-8.

143. Kawahara N, Tanaka T, Yokomizo A, Nanri H, Ono M, Wada M, Kohno K, Takenaka K, Sugimachi K, Kuwano M. Enhanced coexpression of thioredoxin and high mobility group protein 1 genes in human hepatocellular carcinoma and the possible association with decreased sensitivity to cisplatin. Cancer Res. 1996;56(23):5330-3.

144. Sasada T, Iwata S, Sato N, Kitaoka Y, Hirota K, Nakamura K, Nishiyama A, Taniguchi Y, Takabayashi A, Yodoi J. Redox control of resistance to cis-diamminedichloroplatinum (II) (CDDP): protective effect of human thioredoxin against CDDP-induced cytotoxicity. J Clin Invest. 1996;97(10):2268-76. 
145. Koontongkaew S. The tumor microenvironment contribution to development, growth, invasion and metastasis of head and neck squamous cell carcinomas. J Cancer. 2013;4(1):66-83.

146. Bertino EM, Williams TM, Nana-Sinkam SP, Shilo K, Chatterjee M, Mo X, Rahmani M, Phillips GS, Villalona-Calero MA, Otterson GA. Stromal caveolin-1 Is associated with response and survival in a phase II Trial of nab-paclitaxel with carboplatin for advanced NSCLC patients. Clin Lung Cancer. 2015;16(6):466-74.

147. Di Vizio D, Morello M, Sotgia F, Pestell RG, Freeman MR, Lisanti MP. An absence of stromal caveolin-1 is associated with advanced prostate cancer, metastatic disease and epithelial Akt activation. Cell Cycle. 2009:8(15):2420-4.

148. He Y, Zhao X, Gao J, Fan L, Yang G, Cho WC, Chen H. Quantum dotsbased immunofluorescent imaging of stromal fibroblasts Caveolin-1 and light chain 3B expression and identification of their clinical significance in human gastric cancer. Int J Mol Sci. 2012;13(11):13764-80.

149. Shan T, Lu H, Ji H, Li Y, Guo J, Chen X, Wu T. Loss of stromal caveolin-1 expression: a novel tumor microenvironment biomarker that can predict poor clinical outcomes for pancreatic cancer. PLoS ONE. 2014:9(6):e97239.

150. Sloan EK, Ciocca DR, Pouliot N, Natoli A, Restall C, Henderson MA, Fanelli MA, Cuello-Carrion FD, Gago FE, Anderson RL. Stromal cell expression of caveolin-1 predicts outcome in breast cancer. Am J Pathol. 2009;174(6):2035-43.

151. Witkiewicz AK, Dasgupta A, Sotgia F, Mercier I, Pestell RG, Sabel M, Kleer CG, Brody JR, Lisanti MP. An absence of stromal caveolin-1 expression predicts early tumor recurrence and poor clinical outcome in human breast cancers. Am J Pathol. 2009;174(6):2023-34.

152. Zhao Z, Han FH, Yang SB, Hua LX, Wu JH, Zhan WH. Loss of stromal caveolin-1 expression in colorectal cancer predicts poor survival. World J Gastroenterol. 2015;21(4):1140-7.

153. Bonuccelli G, Whitaker-Menezes D, Castello-Cros R, Pavlides S, Pestell RG, Fatatis A, Witkiewicz AK, Vander Heiden MG, Migneco G, Chiavarina $B$, et al. The reverse Warburg effect: glycolysis inhibitors prevent the tumor promoting effects of caveolin-1 deficient cancer associated fibroblasts. Cell Cycle. 2010;9(10):1960-71.

154. Martinez-Outschoorn UE, Balliet RM, Rivadeneira DB, Chiavarina B, Pavlides S, Wang C, Whitaker-Menezes D, Daumer KM, Lin Z, Witkiewicz AK, et al. Oxidative stress in cancer associated fibroblasts drives tumor-stroma co-evolution: a new paradigm for understanding tumor metabolism, the field effect and genomic instability in cancer cells. Cell Cycle. 2010;9(16):3256-76.

155. Pavlides S, Vera I, Gandara R, Sneddon S, Pestell RG, Mercier I, MartinezOutschoorn UE, Whitaker-Menezes D, Howell A, Sotgia F, et al. Warburg meets autophagy: cancer-associated fibroblasts accelerate tumor growth and metastasis via oxidative stress, mitophagy, and aerobic glycolysis. Antioxid Redox Signal. 2012;16(11):1264-84.

156. Neofytou K, Pikoulis E, Petrou A, Agrogiannis G, Petrides C, Papakonstandinou I, Papalambros A, Aggelou A, Kavatzas N, Liakakos T, et al. Weak stromal Caveolin-1 expression in colorectal liver metastases predicts poor prognosis after hepatectomy for liver-only colorectal metastases. Sci Rep. 2017;7(1):2058.

157. Taraboletti G, Morbidelli L, Donnini S, Parenti A, Granger HJ, Giavazzi R, Ziche $M$. The heparin binding $25 \mathrm{kDa}$ fragment of thrombospondin-1 promotes angiogenesis and modulates gelatinase and TIMP-2 production in endothelial cells. FASEB J. 2000;14(12):1674-6.

158. Wang $X Q$, Lindberg FP, Frazier WA. Integrin-associated protein stimulates alpha2beta1-dependent chemotaxis via Gi-mediated inhibition of adenylate cyclase and extracellular-regulated kinases. J Cell Biol. 1999;147(2):389-400.

159. Sutton CD, O'Byrne K, Goddard JC, Marshall LJ, Jones L, Garcea G, Dennison AR, Poston G, Lloyd DM, Berry DP. Expression of thrombospondin-1 in resected colorectal liver metastases predicts poor prognosis. Clin Cancer Res. 2005;11(18):6567-73.

160. Teraoku H, Morine Y, Ikemoto T, Saito Y, Yamada S, Yoshikawa M, Takasu C, Higashijima J, Imura S, Shimada M. Role of thrombospondin-1 expression in colorectal liver metastasis and its molecular mechanism. J Hepatobiliary Pancreat Sci. 2016;23(9):565-73.

161. Kodama J, Hashimoto I, Seki N, Hongo A, Yoshinouchi M, Okuda H, Kudo T. Thrombospondin-1 and -2 messenger RNA expression in invasive cervical cancer: correlation with angiogenesis and prognosis. Clin Cancer Res. 2001;7(9):2826-31.

162. Yamaguchi M, Sugio K, Ondo K, Yano T, Sugimachi K. Reduced expression of thrombospondin-1 correlates with a poor prognosis in patients with non-small cell lung cancer. Lung Cancer. 2002;36(2):143-50.

163. Ioachim E, Damala K, Tsanou E, Briasoulis E, Papadiotis E, Mitselou A, Charhanti A, Doukas M, Lampri L, Arvanitis DL. Thrombospondin-1 expression in breast cancer: prognostic significance and association with p53 alterations, tumour angiogenesis and extracellular matrix components. Histol Histopathol. 2012;27(2):209-16.

164. Straume $\mathrm{O}$, Akslen LA. Expresson of vascular endothelial growth factor, its receptors (FLT-1, KDR) and TSP-1 related to microvessel density and patient outcome in vertical growth phase melanomas. Am J Pathol. 2001;159(1):223-35.

165. Okada K, Hirabayashi K, Imaizumi T, Matsuyama M, Yazawa N, Dowaki S, Tobita K, Ohtani Y, Tanaka M, Inokuchi S, et al. Stromal thrombospondin-1 expression is a prognostic indicator and a new marker of invasiveness in intraductal papillary-mucinous neoplasm of the pancreas. Biomed Res. 2010;31(1):13-9.

166. Tobita K, Kijima H, Dowaki S, Oida Y, Kashiwagi H, Ishii M, Sugio Y, Sekka T, Ohtani Y, Tanaka M, et al. Thrombospondin-1 expression as a prognostic predictor of pancreatic ductal carcinoma. Int J Oncol. 2002;21(6):1189-95.

167. Ciaramella V, Della Corte CM, Ciardiello F, Morgillo F. Kisspeptin and cancer: molecular interaction, biological functions, and future perspectives. Front Endocrinol (Lausanne). 2018;9:115.

168. Chen Y, Yusenko MV, Kovacs G. Lack of KISS1R expression is associated with rapid progression of conventional renal cell carcinomas. J Pathol. 2011;223(1):46-53.

169. Dhar DK, Naora H, Kubota H, Maruyama R, Yoshimura H, Tonomoto Y, Tachibana M, Ono T, Otani H, Nagasue N. Downregulation of KiSS-1 expression is responsible for tumor invasion and worse prognosis in gastric carcinoma. Int J Cancer. 2004;111(6):868-72.

170. Okugawa Y, Inoue Y, Tanaka K, Toiyama Y, Shimura T, Okigami M, Kawamoto A, Hiro J, Saigusa S, Mohri Y, et al. Loss of the metastasis suppressor gene KiSS1 is associated with lymph node metastasis and poor prognosis in human colorectal cancer. Oncol Rep. 2013;30(3):1449-54.

171. Sun YB, Xu S. Expression of KISS1 and KISS1R (GPR54) may be used as favorable prognostic markers for patients with non-small cell lung cancer. Int J Oncol. 2013;43(2):521-30.

172. Zhu C, Takasu C, Morine Y, Bando Y, Ikemoto T, Saito Y, Yamada S, Imura S, Arakawa Y, Shimada M. KISS1 associates with better outcome via inhibiting matrix metalloproteinase-9 in colorectal liver metastasis. Ann Surg Oncol. 2015;22(Suppl 3):S1516-23.

173. Denning GM. IL-4 and IFN-gamma synergistically increase total polymeric IgA receptor levels in human intestinal epithelial cells. Role of protein tyrosine kinases. J Immunol. 1996;156(12):4807-14.

174. Kaetzel CS. The polymeric immunoglobulin receptor: bridging innate and adaptive immune responses at mucosal surfaces. Immunol Rev. 2005;206:83-99.

175. Kvale D, Lovhaug D, Sollid LM, Brandtzaeg P. Tumor necrosis factoralpha up-regulates expression of secretory component, the epithelial receptor for polymeric Ig. J Immunol. 1988;140(9):3086-9.

176. Rojas R, Apodaca G. Immunoglobulin transport across polarized epithelial cells. Nat Rev Mol Cell Biol. 2002;3(12):944-55.

177. Poger ME, Hirsch BR, Lamm ME. Synthesis of secretory component by colonic neoplasms. Am J Pathol. 1976;82(2):327-38.

178. Kvale D, Norstein J, Meling Gl, Bormer OP, Brandtzaeg P, Langmark F, Rognum TO. Circulating secretory component in relation to early diagnosis and treatment of liver metastasis from colorectal carcinomas. J Clin Pathol. 1992;45(7):568-71.

179. Liu F, Ye P, Bi T, Teng L, Xiang C, Wang H, Li Y, Jin K, Mou X. COLORECTAL polymeric immunoglobulin receptor expression is correlated with hepatic metastasis and poor prognosis in colon carcinoma patients with hepatic metastasis. Hepatogastroenterology. 2014;61(131):652-9.

180. Donahue JP, Vetter ML, Mukhtar NA, D'Aquila RT. The HIV-1 Vif PPLP motif is necessary for human APOBEC3G binding and degradation. Virology. 2008;377(1):49-53. 
181. Guo F, Cen S, Niu M, Saadatmand J, Kleiman L. Inhibition of tRNA(3) (Lys)-primed reverse transcription by human APOBEC3G during human immunodeficiency virus type 1 replication. J Virol. 2006;80(23):11710-22.

182. Huthoff $\mathrm{H}$, Malim MH. Identification of amino acid residues in APOBEC3G required for regulation by human immunodeficiency virus type 1 Vif and Virion encapsidation. J Virol. 2007;81 (8):3807-15.

183. Takaori A. Antiviral defense by APOBEC3 family proteins. Uirusu. 2005;55(2):267-72.

184. Ding Q, Chang CJ, Xie X, Xia W, Yang JY, Wang SC, Wang Y, Xia J, Chen $L$, Cai C, et al. APOBEC3G promotes liver metastasis in an orthotopic mouse model of colorectal cancer and predicts human hepatic metastasis. J Clin Invest. 2011;121(11):4526-36.

185. Lan H, Jin K, Gan M, Wen S, Bi T, Zhou S, Zhu N, Teng L, Yu W. APOBEC3G expression is correlated with poor prognosis in colon carcinoma patients with hepatic metastasis. Int J Clin Exp Med. 2014;7(3):665-72.

186. Waring P, Mullbacher A. Cell death induced by the Fas/Fas ligand pathway and its role in pathology. Immunol Cell Biol. 1999;77(4):312-7.

187. Zimmermann KC, Green DR. How cells die: apoptosis pathways. J Allergy Clin Immunol. 2001;108(4 Suppl):S99-103.

188. Sturm I, Kohne CH, Wolff G, Petrowsky H, Hillebrand T, Hauptmann S, Lorenz M, Dorken B, Daniel PT. Analysis of the p53/BAX pathway in colorectal cancer: low BAX is a negative prognostic factor in patients with resected liver metastases. J Clin Oncol. 1999;17(5):1364-74.

189. Oliver L, Cordel S, Barbieux I, LeCabellec MT, Meflah K, Gregoire M, Vallette FM. Resistance to apoptosis is increased during metastatic dissemination of colon cancer. Clin Exp Metastasis. 2002;19(2):175-80.

190. Wong CW, Lee A, Shientag L, Yu J, Dong Y, Kao G, Al-Mehdi AB, Bernhard EJ, Muschel RJ. Apoptosis: an early event in metastatic inefficiency. Cancer Res. 2001;61(1):333-8.

191. Onodera H, Mori A, Nagayama S, Fujimoto A, Tachibana T, Yonenaga $Y$, Tsuruyama T. Fas/CD95 signaling rather than angiogenesis or proliferative activity is a useful prognostic factor in patients with resected liver metastases from colorectal cancer. Int J Colorectal Dis. 2005;20(6):477-84.

192. de Wit M, Jimenez CR, Carvalho B, Belien JA, Delis-van Diemen PM, Mongera S, Piersma SR, Vikas M, Navani S, Ponten F, et al. Cell surface proteomics identifies glucose transporter type 1 and prion protein as candidate biomarkers for colorectal adenoma-to-carcinoma progression. Gut. 2012;61 (6):855-64.

193. Haber RS, Rathan A, Weiser KR, Pritsker A, Itzkowitz SH, Bodian C, Slater G, Weiss A, Burstein DE. GLUT1 glucose transporter expression in colorectal carcinoma: a marker for poor prognosis. Cancer. 1998;83(1):34-40.

194. Shen YM, Arbman G, Olsson B, Sun XF. Overexpression of GLUT1 in colorectal cancer is independently associated with poor prognosis. Int J Biol Markers. 2011;26(3):166-72.

195. Younes M, Lechago LV, Lechago J. Overexpression of the human erythrocyte glucose transporter occurs as a late event in human colorectal carcinogenesis and is associated with an increased incidence of lymph node metastases. Clin Cancer Res. 1996;2(7):1151-4.

196. Seidner G, Alvarez MG, Yeh Jl, O'Driscoll KR, Klepper J, Stump TS, Wang D, Spinner NB, Birnbaum MJ, De Vivo DC. GLUT-1 deficiency syndrome caused by haploinsufficiency of the blood-brain barrier hexose carrier. Nat Genet. 1998;18(2):188-91.

197. Wang J, Ye C, Chen C, Xiong H, Xie B, Zhou J, Chen Y, Zheng S, Wang L. Glucose transporter GLUT1 expression and clinical outcome in solid tumors: a systematic review and meta-analysis. Oncotarget. 2017;8(10):16875-86.

198. Goos JA, de Cuba EM, Coupe VM, Diosdado B, Delis-Van Diemen PM, Karga C, Belien JA, Menke-Van der Houven van Oordt CW, Geldof AA, Meijer GA, et al. Glucose transporter 1 (SLC2A1) and vascular endothelial growth factor A (VEGFA) predict survival after resection of colorectal cancer liver metastasis. Ann Surg. 2016;263(1):138-45.

199. Riedl CC, Akhurst T, Larson S, Stanziale SF, Tuorto S, Bhargava A, Hricak H, Klimstra D, Fong Y. 18F-FDG PET scanning correlates with tissue markers of poor prognosis and predicts mortality for patients after liver resection for colorectal metastases. J Nucl Med. 2007;48(5):771-5.

200. Blagosklonny MV. Target for cancer therapy: proliferating cells or stem cells. Leukemia. 2006;20(3):385-91.

201. Creighton CJ, Li X, Landis M, Dixon JM, Neumeister VM, Sjolund A, Rimm DL, Wong H, Rodriguez A, Herschkowitz JI, et al. Residual breast cancers after conventional therapy display mesenchymal as well as tumorinitiating features. Proc Natl Acad Sci U S A. 2009;106(33):13820-5.

202. Singh A, Settleman J. EMT, cancer stem cells and drug resistance: an emerging axis of evil in the war on cancer. Oncogene. 2010;29(34):4741-51.

203. Asghar U, Hawkes E, Cunningham D. Predictive and prognostic biomarkers for targeted therapy in metastatic colorectal cancer. Clin Colorectal Cancer. 2010;9(5):274-81.

204. Des Guetz G, Uzzan B, Nicolas P, Cucherat M, Morere JF, Benamouzig R, Breau JL, Perret GY. Microvessel density and VEGF expression are prognostic factors in colorectal cancer. Meta-analysis of the literature. Br J Cancer. 2006;94(12):1823-32.

205. Pavlidis ET, Pavlidis TE. Role of bevacizumab in colorectal cancer growth and its adverse effects: a review. World J Gastroenterol. 2013;19(31):5051-60.

206. Hurwitz HI, Tebbutt NC, Kabbinavar F, Giantonio BJ, Guan ZZ, Mitchell $L$, Waterkamp D, Tabernero J. Efficacy and safety of bevacizumab in metastatic colorectal cancer: pooled analysis from seven randomized controlled trials. Oncologist. 2013;18(9):1004-12.

207. Gruenberger T, Arnold D, Rubbia-Brandt L. Pathologic response to bevacizumab-containing chemotherapy in patients with colorectal liver metastases and its correlation with survival. Surg Oncol. 2012;21(4):309-15.

208. Jubb AM, Hurwitz HI, Bai W, Holmgren EB, Tobin P, Guerrero AS, Kabbinavar F, Holden SN, Novotny WF, Frantz GD, et al. Impact of vascular endothelial growth factor-A expression, thrombospondin-2 expression, and microvessel density on the treatment effect of bevacizumab in metastatic colorectal cancer. J Clin Oncol. 2006;24(2):217-27.

209. Suzuki S, Ichikawa Y, Nakagawa K, Kumamoto T, Mori R, Matsuyama R, Takeda K, Ota M, Tanaka K, Tamura T, et al. High infiltration of mast cells positive to tryptase predicts worse outcome following resection of colorectal liver metastases. BMC Cancer. 2015;15:840.

210. Miyagawa S, Soeda J, Takagi S, Miwa S, Ichikawa E, Noike T. Prognostic significance of mature dendritic cells and factors associated with their accumulation in metastatic liver tumors from colorectal cancer. Hum Pathol. 2004;35(11):1392-6.

211. Brunner SM, Kesselring R, Rubner C, Martin M, Jeiter T, Boerner T, Ruemmele P, Schlitt HJ, Fichtner-Feigl S. Prognosis according to histochemical analysis of liver metastases removed at liver resection. Br J Surg. 2014;101(13):1681-91.

212. Wang Y, Lin HC, Huang MY, Shao Q, Wang ZQ, Wang FH, Yuan YF, Li BK, Wang DS, Ding PR, et al. The Immunoscore system predicts prognosis after liver metastasectomy in colorectal cancer liver metastases. Cancer Immunol Immunother. 2018;67(3):435-44.

213. Turcotte S, Katz SC, Shia J, Jarnagin WR, Kingham TP, Allen PJ, Fong Y, D'Angelica MI, DeMatteo RP. Tumor MHC class I expression improves the prognostic value of T-cell density in resected colorectal liver metastases. Cancer Immunol Res. 2014;2(6):530-7.

214. Shinto E, Hase K, Hashiguchi Y, Sekizawa A, Ueno H, Shikina A, Kajiwara Y, Kobayashi H, Ishiguro M, Yamamoto J. CD8+ and FOXP3+tumorinfiltrating $T$ cells before and after chemoradiotherapy for rectal cancer. Ann Surg Oncol. 2014;21(3):414-21.

215. Dalerba P, Sahoo D, Paik S, Guo X, Yothers G, Song N, Wilcox-Fogel N, Forgo E, Rajendran PS, Miranda SP, et al. CDX2 as a prognostic biomarker in stage II and stage III colon cancer. N Engl J Med. 2016;374(3):211-22.

216. Shigematsu $Y$, Inamura $K$, Mise $Y$, Saiura A, Rehnberg E, Yamamoto $\mathrm{N}$, Ishikawa Y, Takahashi S, Kanda H. CDX2 expression is concordant between primary colorectal cancer lesions and corresponding liver metastases independent of chemotherapy: a single-center retrospective study in Japan. Oncotarget. 2018;9(24):17056-65.

217. Shigematsu Y, Inamura K, Yamamoto N, Mise Y, Saiura A, Ishikawa Y, Takahashi S, Kanda H. Impact of CDX2 expression status on the survival of patients after curative resection for colorectal cancer liver metastasis. BMC Cancer. 2018;18(1):980.

218. Toth C, Sukosd F, Valicsek E, Herpel E, Schirmacher P, Tiszlavicz L. Loss of CDX2 gene expression is associated with DNA repair proteins and is a crucial member of the Wnt signaling pathway in liver metastasis of colorectal cancer. Oncol Lett. 2018;15(3):3586-93.

219. Naxerova $K$, Reiter JG, Brachtel E, Lennerz JK, van de Wetering M, Rowan A, Cai T, Clevers H, Swanton C, Nowak MA, et al. Origins of 
lymphatic and distant metastases in human colorectal cancer. Science. 2017:357(6346):55-60.

220. Knijn N, Mekenkamp LJ, Klomp M, Vink-Borger ME, Tol J, Teerenstra S, Meijer JW, Tebar M, Riemersma S, van Krieken JH, et al. KRAS mutation analysis: a comparison between primary tumours and matched liver metastases in 305 colorectal cancer patients. Br J Cancer. 2011;104(6):1020-6.
221. Stange DE, Engel F, Longerich T, Koo BK, Koch M, Delhomme N, Aigner $M$, Toedt G, Schirmacher P, Lichter P, et al. Expression of an ASCL2 related stem cell signature and IGF2 in colorectal cancer liver metastases with 11p15.5 gain. Gut. 2010;59(9):1236-44.
Ready to submit your research? Choose BMC and benefit from:

- fast, convenient online submission

- thorough peer review by experienced researchers in your field

- rapid publication on acceptance

- support for research data, including large and complex data types

- gold Open Access which fosters wider collaboration and increased citations

- maximum visibility for your research: over 100M website views per year

At BMC, research is always in progress.

Learn more biomedcentral.com/submissions 